\title{
Regional trends in the fractional solubility of Fe and other metals from North Atlantic aerosols (GEOTRACES cruises GA01 and GA03) following a two-stage leach
}

\author{
Rachel U. Shelley ${ }^{1,2,3}$, William M. Landing ${ }^{1}$, Simon J. Ussher ${ }^{2}$, Helene Planquette ${ }^{3}$, and Geraldine Sarthou ${ }^{3}$ \\ ${ }^{1}$ Dept. Earth, Ocean and Atmospheric Science, Florida State University, 117 N Woodward Ave, \\ Tallahassee, Florida, 32301, USA \\ ${ }^{2}$ School of Geography, Earth and Environmental Sciences, University of Plymouth, Drake Circus, Plymouth, PL4 8AA, UK \\ ${ }^{3}$ Laboratoire des Sciences de l'Environnement Marin, UMR 6539 LEMAR (CNRS/UBO/IRD/IFREMER), \\ Institut Universitaire Européen de la Mer, Technopôle Brest-Iroise, Plouzané 29280, France
}

Correspondence: Rachel U. Shelley (rshelley@fsu.edu)

Received: 9 October 2017 - Discussion started: 1 November 2017

Revised: 21 March 2018 - Accepted: 22 March 2018 - Published: 18 April 2018

\begin{abstract}
The fractional solubility of aerosol-derived trace elements deposited to the ocean surface is a key parameter of many marine biogeochemical models. Despite this, it is currently poorly constrained, in part due to the complex interplay between the various processes that govern the solubilisation of aerosol trace elements. In this study, we used a sequential two-stage leach to investigate the regional variability in fractional solubility of a suite of aerosol trace elements ( $\mathrm{Al}, \mathrm{Ti}, \mathrm{Fe}, \mathrm{Mn}, \mathrm{Co}, \mathrm{Ni}, \mathrm{Cu}, \mathrm{Zn}, \mathrm{Cd}$, and $\mathrm{Pb}$ ) from samples collected during three GEOTRACES cruises to the North Atlantic Ocean (GA01, GA03-2010, and GA03-2011). We present aerosol trace element solubility data from two sequential leaches that provide a "solubility window", covering a conservative lower limit to an upper limit, the maximum potentially soluble fraction, and discuss why this upper limit of solubility could be used as a proxy for the bioavailable fraction in some regions.

Regardless of the leaching solution used in this study (mild versus strong leach), the most heavily loaded samples generally had the lowest solubility. However, there were exceptions. Manganese fractional solubility was relatively uniform across the full range of atmospheric loading (32 \pm 13 and $49 \pm 13 \%$ for ultra high-purity water and $25 \%$ acetic acid leaches, respectively). This is consistent with other marine aerosol studies. Zinc and $\mathrm{Cd}$ fractional solubility also appeared to be independent of atmospheric loading. Although the average fractional solubilities of $\mathrm{Zn}$ and $\mathrm{Cd}(37 \pm 28$ and $55 \pm 30 \%$ for $\mathrm{Zn}$ and $39 \pm 23$ and $58 \pm 26 \%$ for $\mathrm{Cd}$, for ultra
\end{abstract}

high-purity water and $25 \%$ acetic acid leaches, respectively) were similar to $\mathrm{Mn}$, the range was greater, with several samples being $100 \%$ soluble after the second leach. Finally, as the objective of this study was to investigate the regional variability in TE solubility, the samples were grouped according to air mass back trajectories (AMBTs). However, we conclude that AMBTs are not sufficiently discriminating to identify the aerosol sources or the potential effects of atmospheric processing on the physicochemical composition and solubility of the aerosols.

\section{Introduction}

Aerosol trace element (TE) solubility is a key parameter of many biogeochemical models, but it is poorly constrained, e.g. Fe solubility estimates range from 0.001 to $90 \%$ (Aguilar-Islas et al., 2010; Baker et al., 2016). The fractional solubility (herein referred to as "solubility") of aerosol TEs is defined in terms of the amount of a TE in solution from any given leach that passes through a filter (usually $<0.45$ or $0.2 \mu \mathrm{m}$ ), expressed as a percentage of the total (Baker and Croot, 2010; Baker et al., 2016; Jickells et al., 2016). While this operational definition accounts for some of the variability in published values, it does not account for all of it. A number of factors impact aerosol TE solubility, such as (1) the choice of leaching protocol and 
(2) the aerosol source, which in turn is impacted by a combination of factors such as the mineralogy of the particles, atmospheric processing during transport, and the presence or absence of emissions from e.g. vehicles, industry, and agricultural practices. Several studies have concluded that the most significant effects on aerosol Fe solubility result from the source/composition of the aerosols, rather than changes in physicochemical parameters, such as temperature, $\mathrm{pH}$, and oxygen concentration of the leach medium, or the choice of batch versus flow-through techniques (e.g. Aguilar-Islas et al., 2010; Fishwick et al., 2014).

There have been a number of studies that have focused on the role of aerosol TEs on biogeochemical cycles in the North Atlantic (e.g. Sarthou et al., 2003; Baker et al., 2013; Buck et al., 2010; Ussher et al., 2013; Powell et al., 2015). More recently, the GEOTRACES programme has produced a number of aerosol datasets, which has stimulated further discussion on the use of these data to look for trends that link TE solubility and aerosol source (e.g. Baker et al., 2016; Jickells et al., 2016). Elemental ratios, enrichment factors, and air mass back trajectory (AMBT) simulations have long been used as a first approximation of aerosol source, and there are many studies that employ multivariate statistical analyses for aerosol source apportionment (e.g. Chueinta et al., 2000; Laing et al., 2015). In addition, more studies are making use of stable isotope ratios to investigate aerosol provenance. Some of these methods are well-established and have a relatively long history of use in this purpose, such as $\mathrm{Pb}$ isotopes (e.g. Maring et al., 1987) and $\mathrm{Sr}$ and $\mathrm{Nd}$ isotopes (e.g. Skonieczny et al., 2011; Scheuvens et al., 2013, and references therein), and data from investigations of novel isotope systems are increasing. For example, Fe isotopes show promise as a way to differentiate between anthropogenic and mineral dust aerosols (Conway et al., 2018). In contrast, $\mathrm{Cd}$ isotopes may not be a suitable tool for aerosol source apportionment (Bridgestock et al., 2017).

As the soluble fractions of aerosol TEs are thought to be the most readily bioavailable forms (Shaked and Lis, 2009), the leachable (soluble) fraction is used as a first approximation of the bioavailable fraction. Therefore, experimental conditions should mimic natural conditions as closely as possible, while yielding reproducible results. Ideally, the leach protocol used fits both these criteria. However, that is not always strictly possible for reasons such as access to the leach medium of choice, availability of analytical instrumentation, and cost. Currently, however, there is no standardised aerosol leaching protocol, but it is recognised that this should be a priority for future studies (Baker et al., 2016). Some commonly used leach media are ultra high-purity (UHP) water $\left(18.2 \mathrm{M} \Omega \mathrm{cm}^{-1}\right)$, seawater, weak acids (e.g. $1 \% \mathrm{HCl}, 25 \%$ acetic acid), or ammonium acetate buffer (e.g. Buck et al., 2006, Baker et al., 2006b; Berger et al., 2008).

To investigate the regional variation in the solubility of key TEs in the North Atlantic, aerosol samples were collected during the US GEOTRACES GA03 campaigns in 2010 and
2011, and the French GEOTRACES GA01 campaign in 2014 (www.geotraces.org, last access: 14 February 2018). The focus of this paper is $\mathrm{Fe}$ and the GEOTRACES "key" trace elements, $\mathrm{Al}, \mathrm{Cd}, \mathrm{Cu}, \mathrm{Mn}, \mathrm{Pb}$, and $\mathrm{Zn}$, plus $\mathrm{Co}, \mathrm{Ni}$, and $\mathrm{Ti}$ (GEOTRACES Planning Group, 2006). This suite of TEs includes bioactive elements, tracers of atmospheric deposition, and elements characteristic of anthropogenic aerosols. Some TEs fit into more than one of these categories. Here, we use the term "trace element" in the context of open ocean water column concentrations, thus acknowledging that elements such as $\mathrm{Al}, \mathrm{Fe}$, and $\mathrm{Ti}$ are not present in trace concentrations in aerosol source material. Aerosol concentrations for a suite of other elements ( $\mathrm{Li}, \mathrm{Na}, \mathrm{Mg}, \mathrm{P}, \mathrm{Sc}, \mathrm{V}, \mathrm{As}, \mathrm{Se}, \mathrm{Rb}$, $\mathrm{Sr}, \mathrm{Sn}, \mathrm{Sb}, \mathrm{Cs}, \mathrm{Ba}, \mathrm{La}, \mathrm{Ce}, \mathrm{Nd}$, Th, U) were also determined, but will not be discussed further here. However, these data are available at BCO-DMO (GA03; www.bco-dmo.org/, last access: 14 February 2018) and BODC (GA01; https://www. bodc.ac.uk/geotraces/data/inventories/geovide/, last access: 13 April 2018) and on request from the lead author.

In this study a two-stage leach protocol was followed. the first leach employed was the "instantaneous" leach described by Buck et al. (2006), which is a flow-through method in which the leach medium is in contact with the aerosols for $10-30$ s. It can be conducted using UHP water or seawater. The advantages of using UHP water are that UHP water is a reproducible medium (allowing for inter-lab comparisons) that can easily be analysed by inductively coupled plasma mass spectrometry (ICP-MS) for many elements simultaneously without the need for time-consuming sample handling steps such as separation techniques and drying down then re-dissolving the residue. Leaches with UHP water can be conducted at sea or in the home laboratory. If fresh seawater is used the leaches must be undertaken at sea.

Given that UHP water and rainwater have broadly similar $\mathrm{pH}(\sim \mathrm{pH} 5.6)$, UHP water is used as an analogue for rain/wet deposition, as wet deposition is thought to dominate the supply of many TEs, at least at some regional and local scales (Helmers and Shremms, 1995; Kim et al., 1999; Powell et al., 2015). However, the extremely low ionic strength of UHP water, as well as the absence of the metal binding ligands naturally present in rainwater and seawater (e.g. Cheize et al., 2012; Wozniak et al., 2014), means that UHP water is not a perfect analogue for oceanic receiving waters. As such, freshly collected, filtered $(<0.2 \mu \mathrm{m})$ seawater likely produces a better estimate of the fractional solubility of TEs on first contact with oceanic receiving waters. For $\mathrm{Fe}$, leaches using UHP water ( $\sim \mathrm{pH} 5.6)$ typically produce higher solubility estimates than leaches conducted with natural seawater $(\sim \mathrm{pH} 8.2)$ due to the $\mathrm{pH}$ sensitivity of dissolution and the higher ionic strength of seawater. On occasions where higher solubility in seawater is observed, complexation by Fe binding ligands is likely the cause. Regardless of whether UHP water or seawater is used, the instantaneous leach likely yields conservative lower-limit estimates of TE solubility due to the short contact time between the aerosols 
and leach medium and reports that aerosol solubility has a bimodal behaviour for many TEs (initial fast release, followed by a slower sustained release with time; e.g. Desboeufs et al., 2005; Koçak et al., 2007; Mackey et al., 2015).

The second sequential leach was employed in order to estimate an upper limit of TE solubility and provide a "solubility window", but it was also an estimate of the maximum bioavailable fraction during the residence time of aerosol particles in the euphotic zone. We used the $25 \%$ acetic acid leach with hydroxylamine hydrochloride described by Berger et al. (2008). The $\mathrm{pH}$ of this leach (pH 2.1) is just below that of zooplankton or fish digestive tracts and the reducing agent mimics the low-oxygen environments inside faecal pellets and marine snow aggregates. Indeed, Schmidt et al. (2016) have demonstrated that lithogenic Fe is mobilised in the gut passage of krill, resulting in 3-fold higher Fe content in the muscle and 5-fold higher Fe content of the faecal pellets of specimens close to lithogenic source material compared to those from offshore.

\section{Methods}

\subsection{Aerosol sample collection}

Aerosol samples $(n=57)$ were collected aboard the $\mathrm{R} / \mathrm{V}$ Knorr during the US GEOTRACES GA03 cruises (15 October-2 November 2010 and 6 November-9 December 2011) and aboard the N/O Pourquoi Pas? during the French GEOTRACES GA01 cruise (GEOVIDE, 15 May-30 June 2014) (Fig. 1). Both campaigns took place in the North Atlantic Ocean, with GA03-2010 and GA01 departing from Lisbon, Portugal. The cruise tracks were designed to traverse a wide variety of biogeochemical provinces (Longhurst, 1998), including continental shelf regions, an eastern boundary current upwelling system (off West Africa), the oligotrophic North Atlantic gyre, and sub-Arctic waters, and to span a large gradient in atmospheric dust loading. The aerosol collections have been described previously (Wozniak et al., 2013, 2014; Shelley et al., 2015, 2017). Briefly, air was simultaneously pulled through 12 acid-washed $47 \mathrm{~mm}$ diameter Whatman 41 (W41) ashless filter discs at approximately $1.2 \mathrm{~m}^{3} \mathrm{~min}^{-1}\left(134 \mathrm{~cm} \mathrm{~s}^{-1}\right.$ face velocity) using a highvolume aerosol sampler (TSP model 5170V-BL, Tisch Environmental). The metadata and concentration data for the aerosol leaches can be found in the Supplement (Table S1). All filters were stored frozen $\left(-20^{\circ} \mathrm{C}\right)$ and double bagged prior to processing, both on the ship and upon returning to the home laboratories.

To avoid contamination from the ship's stack exhaust, aerosol sampling was controlled with respect to wind sector and wind speed using an anemometer interfaced with a data logger (CR800, Campbell Scientific). The samplers were programmed to run when the wind was $\pm 60^{\circ}$ from the bow of the ship and $>0.5 \mathrm{~m} \mathrm{~s}^{-1}$. When the wind failed to

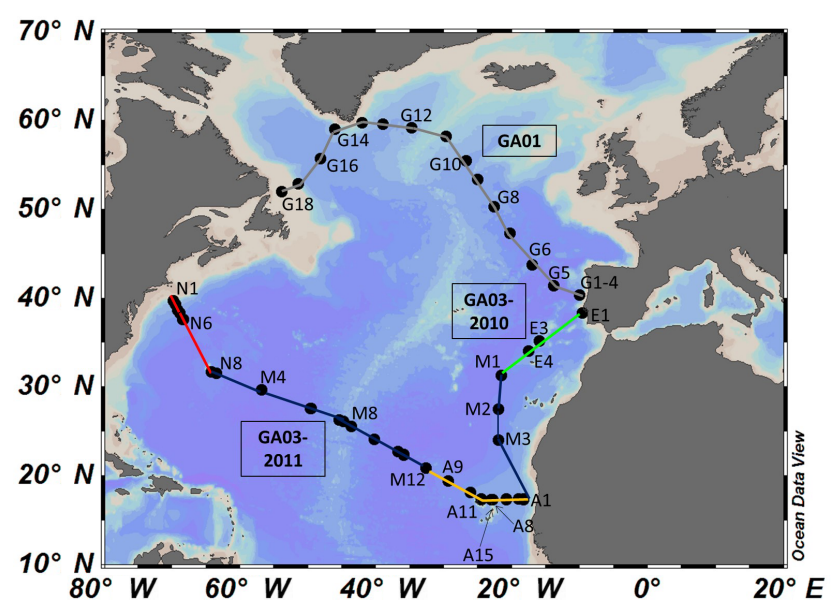

Figure 1. The GEOTRACES GA01 and GA03 cruise tracks (GA01, GA03-2010, and GA03-2011). In total, 57 aerosol samples (GA01 $n=18$, GA03 $n=39$; black dots) were collected. The samples are grouped by aerosol source region (green is European (E1-4), blue is Marine (M1-12), yellow is North African (A1-15), red is North American (N1-8), and grey is High Latitude (G1-18)), identified from air mass back trajectory simulations using the NOAA ARL model, HYSPLIT (Stein et al., 2015; Rolph, 2017). Note that a different labelling convention was used in Shelley et al. (2017) to refer to the GA01 samples. Here we use G1-18 to refer to the samples collected during GA01 (A1-18 in Shelley et al., 2017) and A1-15 to refer to the North African samples from GA03.

meet these two criteria, the motors were shut off automatically and not allowed to restart until the wind met both the speed and direction criteria for 5 continuous minutes. In addition, the samplers were deployed on the ship's flying bridge as high off the water as possible $(\sim 14 \mathrm{~m}$ above sea level) to minimise collection of sea spray.

\subsection{Trace element determination - totals aerosol TEs}

The total digestion method of Morton et al. (2013) was used for the determination of total aerosol TE loadings (Al, Ti, $\mathrm{Mn}, \mathrm{Fe}, \mathrm{Co}, \mathrm{Ni}, \mathrm{Cu}, \mathrm{Zn}, \mathrm{Cd}, \mathrm{Pb}$ ). The W41 filter discs were digested in tightly capped $15 \mathrm{~mL}$ Teflon PFA vials (Savillex). Firstly, $1000 \mu \mathrm{L}$ of UHP $15.8 \mathrm{M}$ nitric acid (Optima or Merck Ultrapur) was added to each vial, heated to $150{ }^{\circ} \mathrm{C}$ on a hotplate, and then taken to dryness. Secondly, $500 \mu \mathrm{L}$ of $15.8 \mathrm{M}$ nitric acid (final concentration $=13.2 \mathrm{MHNO}_{3}$ ) and $100 \mu \mathrm{L}$ of $28.9 \mathrm{M}$ hydrofluoric acid (final concentration $=5.8 \mathrm{M} \mathrm{HF}$ ) (Optima or Merck Ultrapur) was added to each vial, reheated to $150^{\circ} \mathrm{C}$ on a hotplate, then taken to near dryness. After the final digestion and evaporation step, the samples were re-dissolved in $20 \mathrm{~mL}$ of $0.32 \mathrm{M}$ nitric acid for analysis. All filter digestions were performed under Class-100 laminar flow conditions. Total aerosol TE concentrations were determined by magnetic sector field ICP-MS (Thermo Element-2) at the National High Magnetic Field Laboratory (NHMFL) at Florida State University (FSU; GA03) or Pôle de Spec- 
trométrie Océan (PSO) at the Institut Universitaire Européen de la Mer, France (IUEM; GA01). Samples were introduced to a PFA-ST nebuliser (Elemental Scientific Inc.) via a modified SC-Fast introduction system consisting of an SC-2 autosampler, a six-port valve, and a vacuum rinsing pump. Replicate blank solutions for the acid digestions were prepared by digesting W41 discs that had been deployed in the aerosol samplers for $1 \mathrm{~h}$ while not in operation, and the resulting concentrations were subtracted from all acid-digested filter samples. Details of the digestion blanks and analytical figures of merit, including certified reference material recoveries, have previously been reported (Shelley et al., 2015, 2017).

\subsection{Trace element determination - soluble aerosol TEs}

In this study, we used a two-step sequential leach to investigate regional variation in aerosol sources, TE fractional solubility and bioavailability. We discuss the results from (1) an "instantaneous" leach (Buck et al., 2006), which provides a lower-limit estimate of the most labile TE fraction (analogous to the initial rapid release of TEs into raindrops and the surface mixed layer of the ocean), followed by (2) a more protracted leach using $25 \%$ acetic acid (with the reducing agent, hydroxylamine hydrochloride, and heat, $10 \mathrm{~min}$ at $90^{\circ} \mathrm{C}$ ), which mimics the slower and sustained release from aerosol particles during their residence time in the euphotic zone.

The first step, the "instantaneous" leach, was conducted under a Class-100 laminar flow hood. In this technique, $100 \mathrm{~mL}$ of UHP water $\left(>18 \mathrm{M} \Omega \mathrm{cm}^{-1}\right.$ resistivity, $\mathrm{pH} \sim 5.5$, Barnstead Nanopure) is rapidly passed through an aerosolladen W41 filter held in a polysulfone vacuum filtration assembly (Nalgene). Operationally defined dissolved $(\leq 0.45 \mu \mathrm{m})$ TEs are collected in the filtrate (leachate) by positioning a GN-6 Metricel backing filter (cellulose esters) below the W41 disc in the filtration assembly (Buck et al., 2006). In this study, the leachate was transferred to an acidclean low-density polyethylene (LDPE) bottle and acidified to $0.024 \mathrm{M}$ ( pH 1.7) with UHP $\mathrm{HCl}$ and double-bagged for storage until analysis at FSU or IUEM. As for total elemental determinations, soluble TEs in the leachate were also determined by ICP-MS. Leachate blanks were prepared by passing $100 \mathrm{~mL}$ of UHP water through W41 filters that had been deployed in the aerosol sampler for $1 \mathrm{~h}$ while not in operation. For example, leachate blanks for Fe represented an average of $1.6 \pm 0.4$ and $15.5 \pm 15.8 \%$ of the Fe sample concentrations for GA03 and GA01, respectively). A subset of samples (GA03-2011) were also leached using the instantaneous leach procedure with freshly collected, filtered $(0.2 \mu \mathrm{m})$ seawater as the leach medium. Leachate blanks were subtracted from all leachate sample concentrations, details of which can be found in Table S1 in the Supplement.
The UHP water fractional solubility was calculated using Eq. (1):

$$
\begin{aligned}
& \frac{[\text { element }]_{\text {UHP water leach }}}{[\text { element }]_{\text {total }}} \cdot 100 \\
& =\text { UHP water fractional solubility. }
\end{aligned}
$$

Following the instantaneous UHP water leach, the filter was transferred to a $15 \mathrm{~mL}$ centrifuge tube, and the second leach was undertaken, using $5 \mathrm{~mL}$ of $25 \%$ (4.4 M) ultra pure acetic acid, with $0.02 \mathrm{M}$ hydroxylamine hydrochloride as the reducing agent (Berger et al., 2008). After a 10 min heating step $\left(90^{\circ} \mathrm{C}\right)$, the leaches were left for $24 \mathrm{~h}$ before being centrifuged for $5 \mathrm{~min}$ at $3400 \times$ gravity. The leachate was then carefully decanted into acid-clean LDPE bottles. In order to rinse any residual acetic acid from the filter, $5 \mathrm{~mL}$ of UHP water was pipetted into the centrifuge tubes, which were then centrifuged again for $5 \mathrm{~min}$ at $3400 \mathrm{xg}$. This supernatant was then added to the acetic acid leachate in the LDPE sample bottles. As this second leach aims to access a less labile fraction of the TEs of interest (including TEs absorbed to surfaces, TE oxyhydroxides and TEs complexed by aerosol organic matter), without significantly attacking TEs bound within the mineral matrix (Koçak et al., 2007; Berger et al., 2008), it may provide an upper-limit estimate for the fractional solubility of these aerosol TEs as the aerosols mix down into the ocean. There is a slight risk that the heating step could begin to attack the mineral matrix, resulting in a slight overestimation of the upper limit of solubility, but this risk was shown to be minimal (Berger et al., 2008). Despite this risk, the heating step was included because of the desire for procedural similarity with marine particle leaches from the same cruises (e.g. Planquette et al., 2016; Hélène Planquette and Arthur Gourain personal communication, 2018), which have been used to assess the relative importance of atmospheric inputs of TEs to water column concentrations of $\mathrm{Al}, \mathrm{Fe}$, and $\mathrm{Pb}$ (Menzel Barraqueta et al., 2018; Tonnard et al., 2018; Zurbrick et al., 2018).

As all samples in this study were leached first using the UHP water instantaneous leach, followed by a sequential leach with $25 \%$ acetic acid, the overall solubility in $25 \%$ acetic acid was calculated using Eq. (2):

$$
\begin{aligned}
& \frac{[\text { element }] \text { UHP water leach }}{[\text { element }]_{\text {total }}}+\frac{[\text { element }] 25 \% \text { HAc leach }}{[\text { element }]_{\text {total }}} \cdot 100 \\
& =\text { HAc fractional solubility. }
\end{aligned}
$$

\subsection{Major anion determination}

Before the UHP water leachate was acidified, a $10 \mathrm{~mL}$ aliquot was taken from each leach sample for the determination of the soluble major anions. The aliquot was immediately frozen for storage. The anions, $\mathrm{Cl}^{-}, \mathrm{NO}_{3}^{-}$, and $\mathrm{SO}_{4}^{2-}$, were determined by ion chromatography using either a Dionex 4500i (at FSU for GA03 samples) or a Metrohm 850 Professional IC system (at Laboratoire Interunivesitaire des Systèmes Atmosphériques, Paris, for GA01 samples). 


\subsection{Air mass back trajectory simulations}

AMBT simulations were generated using the publicly available NOAA Air Resources Laboratory Hybrid SingleParticle Lagrangian Integrated Trajectory (HYSPLIT) model, using the GDAS meteorology (Stein et al., 2015; Rolph, 2017). The 5-day AMBT simulations were used to describe five regional categories, based on the predominant trajectories for the air masses. The simulations and further details of these categories can be found in Wozniak et al. $(2013,2014)$ and Shelley et al. (2015, 2017). Briefly, for cruise GA03 air masses were characterised as European, North American, North African, or Marine (no or minimal interaction with major continental land masses within the 5-day simulation period). For cruise GA01, all the samples were classified as High Latitude dust (originating north of $50^{\circ} \mathrm{N}$; Bullard et al., 2016). The classifications are shown in Table S1, and the AMBT simulations from Shelley et al. $(2015,2017)$ have been reproduced and can be found in the Supplement (Fig. S1). The simulations use arrival heights of 50,500 , and $1500 \mathrm{~m}$, so that at least one height was located in the marine boundary layer.

\section{Results and discussion}

\subsection{Identifying aerosol provenance}

AMBT simulations are frequently used to identify the origin and/or flow path of air masses, from which a first approximation of aerosol provenance (e.g. deserts, urban regions, or biomass burning) is made. Although they are useful tools in oceanographic studies, AMBTs used alone do have limitations. Perhaps the most significant of these is that they are unable to quantify the contribution of different aerosol types or the entrainment of particles along the flow path of the air mass. Indeed, within the five categories described in this study multiple sources are likely to have contributed to the composition of the bulk aerosol of each category. This study is likely to be particularly sensitive to this as the sampling site was not static (i.e. sampling occurred along three different transects), and air masses can, and do, take different pathways within a general wind direction. Consequently, AMBTs are not adequately discriminating for aerosol source apportionment. However, we have organised the data using the AMBT categories because the objective of this study was to look for trends in solubility at a regional level, as well as for consistency with our earlier published work from the North Atlantic (Wozniak et al., 2013, 2014; Shelley et al., 2015, 2017).

More powerful approaches for aerosol source apportionment consider the physicochemical composition of the aerosols, either as the bulk aerosol or as individual particles. There have been a number of field campaigns (e.g. DABEX, DODO, SAMUM, and AMMA) and individual studies which have provided a wealth of information about the physicochemical composition of African dust before, during, and after long-range transport (e.g. Johansen et al., 2000; Johnson et al., 2008; McConnell et al., 2008; Petzold et al., 2009; Marticorena et al., 2010; Trapp et al., 2010; Formenti et al., 2011). These studies and satellite data have identified the key dust source regions in North Africa (Prospero et al., 2002). Chemical composition data for other aerosol end members which supply aerosols to the North Atlantic are not as extensive, but some examples of individual studies and field campaigns can be found in Table S2. In addition, campaigns in the Atlantic Ocean which have sampled marine aerosols (e.g. Atlantic Meridional Transect, CLIVAR, GEOTRACES) have identified aerosol sources from characteristic groups of elements and elemental ratios (e.g. high concentrations of lithogenic elements are characteristic of a mineral dust; $\mathrm{K}$ is a tracer of biomass burning; and correlations between $\mathrm{V}$ and $\mathrm{Ni}$ are diagnostic of emissions from marine shipping; Baker et al., 2006a; Sippula et al., 2014; Baker and Jickells, 2017), organic compounds (e.g. Wozniak et al., 2013, 2014, 2015), and/or stable isotopic signatures (Scheuvens et al., 2013, and references therein).

Although atmospheric inputs to the ocean are episodic and exhibit a seasonality in the tropical and subtropical North Atlantic that is largely driven by the migration of the intertropical convergence zone (Prospero et al., 1981; Adams et al., 2012; Doherty et al., 2014), North African/Saharan mineral dust dominated the aerosol composition in the GA03 study region (Conway and John, 2014; Shelley et al., 2015; Conway et al., 2018). Other aerosol sources in Europe and North America and sea salt also contributed to the bulk aerosol to varying extents. In contrast to GA03, the GA01 transect was located north of the extent of the Saharan dust plume $\left(\sim 25^{\circ} \mathrm{N}\right.$ in summer; Ben-Ami et al., 2010$)$ and was thus influenced by a mixture of high-latitude dust sources (Prospero et al., 2012; Shelley et al., 2017), which also have a seasonal cycle. As a result, a large dynamic range of aerosol loading was observed $\left(\mathrm{Fe}=0.185-5650 \mathrm{ng} \mathrm{m}^{-3}\right.$; $\mathrm{Al}=0.761-7490 \mathrm{ng} \mathrm{m}^{-3}$ ) during these two campaigns, with the highest $\mathrm{Fe}$ and $\mathrm{Al}$ loadings associated with the North African samples (GA03), lower loadings with the Marine samples (GA03), and the lowest loadings observed in the samples collected in the Labrador Sea (GA01).

Total $\mathrm{Fe}$ and $\mathrm{Al}$ were strongly correlated $\left(r^{2}=0.999\right.$, Pearson's $\rho P<0.01$ ), demonstrating that the two metals have common lithogenic source(s) (Fig. 2). However, this correlation was largely driven by the heavily loaded North African samples $\left(r^{2}=0.997, P<0.01\right)$. For each of the other source categories, simple linear regression of the data resulted in $r^{2}$ values of $0.879(P<0.01)$ for High Latitude dust (GA01), $0.890(P=0.057)$ for European samples (GA03), $0.983(P=0.34)$ for North American samples (GA03), and $0.751(P=0.70)$ for Marine samples (GA03) (Fig. 2b). Further discussion of sub-regional differences in the $\mathrm{Fe} / \mathrm{Al}$ ratio are addressed later in the Dis- 

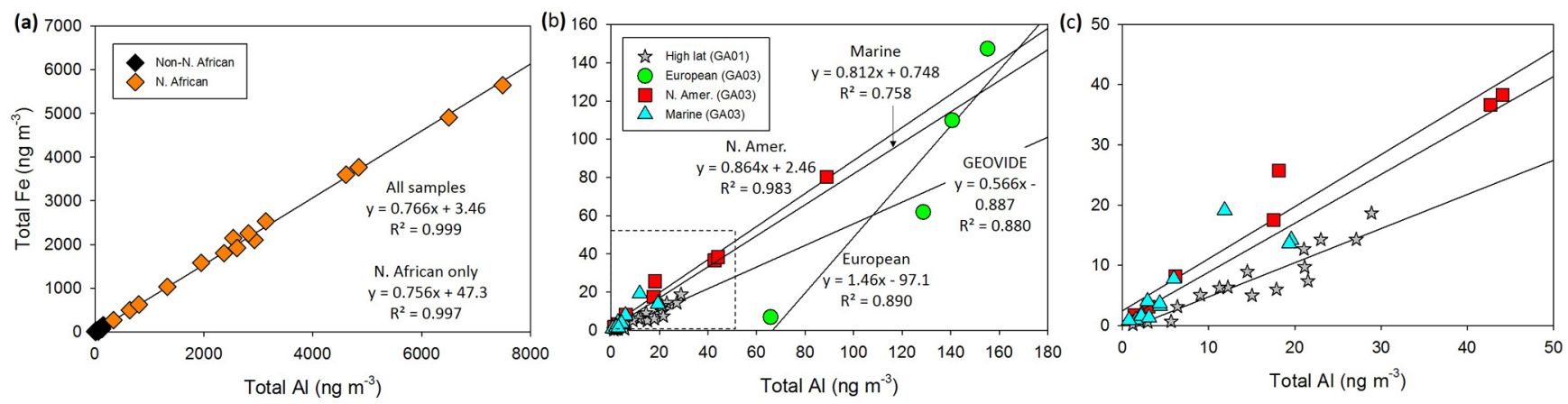

Figure 2. Total aerosol $\mathrm{Fe}$ and $\mathrm{Al}\left(\mathrm{ng} \mathrm{m}^{-3}\right)$ for (a) all aerosol samples from cruises GA01 and GA03, (b) samples from sources other than North Africa (i.e. the black diamonds in a), and (c) the samples inside the dashed box in (b). For High Latitude dust $n=18$, European samples $n=4$, North American samples $n=8$, Marine samples $n=12$, and Saharan samples $n=15$. Note that error bars (standard deviations shown in Table S1) are not included so as not to obscure the symbols.

cussion. For the other TEs, strong correlations for the combined GA01 and GA03 datasets were found between $\mathrm{Ti} / \mathrm{Al}$ $\left(r^{2}=0.999, P<0.01\right), \mathrm{Mn} / \mathrm{Al}\left(r^{2}=0.994, P<0.01\right)$, and $\mathrm{Co} / \mathrm{Al}\left(r^{2}=0.996, P<0.01\right)$, in accord with previous observations in this region, owing to the primarily lithogenic sources of these elements (e.g. Jickells et al., 2016). The correlations between $\mathrm{Al}$ and the primarily anthropogenic TEs $\mathrm{Ni}, \mathrm{Cu}, \mathrm{Zn}, \mathrm{Cd}$, and $\mathrm{Pb}$ - were also significant at the $99 \%$ confidence level due to the presence of the heavily loaded North African samples, which accounted for between 88 and $30 \%$ of the statistical variance for $\mathrm{Ni}$ and $\mathrm{Cd}$, respectively: $\mathrm{Ni} / \mathrm{Al}\left(r^{2}=0.884\right), \mathrm{Cu} / \mathrm{Al}\left(r^{2}=0.652\right), \mathrm{Pb} / \mathrm{Al}$ $\left(r^{2}=0.478\right), \mathrm{Zn} / \mathrm{Al}\left(r^{2}=0.321\right)$, and $\mathrm{Cd} / \mathrm{Al}\left(r^{2}=0.303\right)$. Sources other than mineral dust (e.g. metal smelting emissions, fly ash, vehicle emissions, volcanic ash, proglacial till) are presumably responsible for the residual variance. Establishing the contributions from these other aerosol sources and their influence on TE solubility is a research priority.

As the aerosol source has a direct bearing on the type and composition of aerosols, determining the source could provide useful data that might be used to predict the fractional solubility of aerosol TEs. As positive matrix factorisation (PMF) can be used for source apportionment, we used the US Environmental Protection Agency's EPA PMF model (v. 5.0) with the total TE concentration data to look for trends in the data. However, the GA01 and GA03 dataset is relatively small $(n=57)$ and the model was not stable with more than two factors. The two factors were a mineral dust factor (high contributions from lithogenic TEs, in particular Al, $\mathrm{Ti}, \mathrm{Fe}$, and $\mathrm{Zr}$ ) and a pollution/anthropogenic factor (with high contributions from $\mathrm{Zn}$ and $\mathrm{Pb}$ ) (Fig. S2a in the Supplement). As anticipated, the mineral dust factor dominated where North African aerosols were sampled, and the pollution factor was relatively more important closer to the European and North American continents (Fig. S2b). This is in accord with the samples from North Africa with elemental mass ratios that are consistently the closest to the upper continental crustal (UCC) elemental ratios compared to aerosols from the other source regions (Fig. 3). In the High Latitude samples, the pollution factor and the mineral dust factor were of approximately equal dominance. Interestingly, the North African aerosols also contained a relatively strong pollution component, consistent with a northeast flow into North Africa from Europe, followed by entrainment of mineral dust during passage over the Sahara (Baker and Jickells, 2017). Given that the PMF indicates that $100 \%$ of the variability in the $\mathrm{Cd}$ concentrations was explained by the pollution factor, this suggests that $\mathrm{Cd}$ in North African aerosols is not sourced from mineral dust, which would explain why no fractionation was observed in $\mathrm{Cd}$ isotopes from North African and European aerosols (Bridgestock et al., 2017). Further, it also suggests that even the relatively homogeneous aerosols from North Africa do not represent a "pure" end member. However, the PMF analysis was not sensitive enough to identify the full complement of aerosol sources contributing to the samples collected during GA01 and GA03.

\subsection{Elemental mass ratios and aerosol source}

Elemental mass ratios from the 10 most heavily loaded GA03 North African aerosols were averaged to derive a value for the "North African" ratio depicted by the dashed horizontal line in Fig. 3a-i. Aluminium was used to normalise the data (Fig. 3; Table S2) and was chosen instead of Ti, another proxy for mineral dust, due to the presence of some anomalously high $\mathrm{Ti} / \mathrm{Al}$ ratios in some of the Marine samples during GA03 (Fig. 3a; Shelley et al., 2015). We have previously reported a mass ratio of 0.76 for $\mathrm{Fe} / \mathrm{Al}$ for the North African end member aerosols (Shelley et al., 2015; Fig. 2a), which is significantly higher than the mean UCC ratio of 0.47 (Rudnick and Gao, 2003) but entirely consistent other studies of Saharan soils and dust (e.g. Chiapello et al., 1997; Guieu et al., 2002; Lafon et al., 2006; Baker et al., 2013).

For North African dust there does not appear to be a discernible source-dependent trend in $\mathrm{Fe} / \mathrm{Al}$ ratios due to a natural variability in Fe-bearing minerals in soils in dust source 

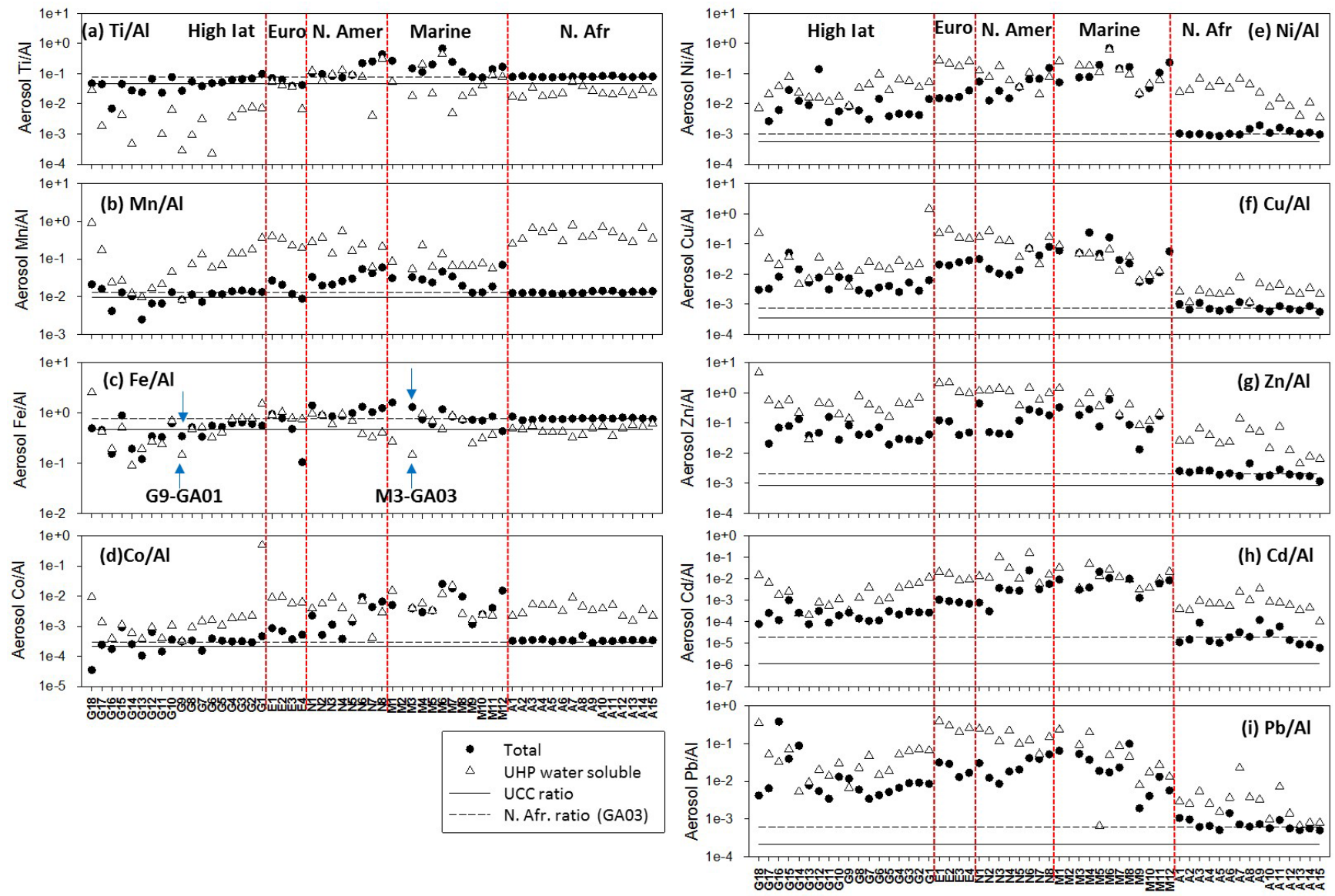

Figure 3. Elemental mass ratios (normalised to $\mathrm{Al}$ ) of total (black circles) and UHP water-soluble (white triangles) TEs. The UCC elemental ratio (Rudnick and Gao, 2003) is indicated by the solid horizontal line, and the elemental ratio in North African sourced aerosols (Shelley et al., 2015) is indicated by the dashed horizontal line on each plot. The red vertical lines separate the aerosol source regions, which are labelled in panel (a). Samples G9-GA01 and M3-GA03 are indicated by blue arrows in panel (c) (see text for details).

regions (Lafon et al., 2006; Scheuvens et al., 2013), but it might be possible to use $\mathrm{Fe} / \mathrm{Al}$ ratios for some of the other aerosol groups to suggest different sources. For example, the European samples $(n=4)$ fall into two sub-groups: two samples have low $\mathrm{Fe} / \mathrm{Al}$ ratios (Fig. 2; E3 $=0.48, \mathrm{E} 4=0.10$ and Fig. 3c), whereas the other two samples $(\mathrm{E} 1=0.95$ and $\mathrm{E} 2=0.78$ ) have $\mathrm{Fe} / \mathrm{Al}$ ratios within the range of the North American samples (Fe / Al 1.1 \pm 0.22 , range 0.86-1.42) and all but one of the Marine samples (Fe / Al, excluding M12, $0.93 \pm 0.33$, range $0.59-1.61 ; \mathrm{M} 12$, collected closest to the North African samples, $\mathrm{Fe} / \mathrm{Al}=0.43$ ).

Aerosols from the more northerly section, GA01, were largely outside the influence of the Saharan dust plume (Shelley et al., 2017) and are all classified as High Latitude in this study (Fig. 3). For this group of samples, there were also subgroups of $\mathrm{Fe} / \mathrm{Al}$ ratios. During the first half of the cruise (Fig. 1), there was a group of samples (G1-6, G8, and G10) with $\mathrm{Fe} / \mathrm{Al}$ ratios of $0.58 \pm 0.05$ (Fig. 3c). This is intermediate between the UCC ratio $(0.48 \pm 0.07)$ and the North African mineral dust ratio $(0.78 \pm 0.03$; Fig. $3 c)$. For these samples, the wind direction was predominantly from the north/north-west (Shelley et al., 2017), so it is unlikely that the observed ratios reflect a mixture of North African mineral dust and European aerosols. Rather, it more likely comes from high-latitude sources, as dust supplied by proglacial till from Iceland and Greenland peaks in spring-early summer and can be deposited over the Atlantic Ocean (Prospero et al., 2012; Bullard et al., 2016). Unfortunately, the extensive cloud cover experienced during the GA01 cruise (MayJune 2014) prevented the use of satellite observations (e.g. http://worldview.earthdata.nasa.gov, last access: 14 February 2018), which would have confirmed the presence of dust from these sources. The elemental ratios calculated from TE concentrations from volcanic ash sampled during the eruption of the Eyjafjallajökull volcano in 2010 (Achterberg et al., 2013) offer some limited support for this argument, as our range of elemental ratios encompasses this end member (Icelandic soils are almost exclusively volcanic in origin; $\mathrm{Ar}$ nalds, 2004). However, although Icelandic sands (Baratoux et al., 2011) and tephra (Oladottir et al., 2011) have Mn/Al 
ratios that overlap the GA01 samples, $\mathrm{Fe} / \mathrm{Al}$ is generally lower in our High Latitude dust samples (Table S2).

A second group of GA01 samples (G7, G9, G11, and G12) had $\mathrm{Fe} / \mathrm{Al}$ ratios of $0.34 \pm 0.01$, but no obvious link in terms of the AMBTs. The Greenland Shelf and Labrador Sea samples, except G15, had low Fe / Al (0.16 \pm 0.04$)$ and were distinct from those collected on the Canadian Shelf $(0.48 \pm 0.02)$. These trends strongly suggest that the High Latitude dust was made up of at least four aerosol sources.

While there is evidence for anthropogenic source(s) of aerosol Fe to the North Atlantic (Conway et al., 2018), which is more soluble than $\mathrm{Fe}$ associated with mineral dust (Sedwick et al., 2007; Sholkovitz et al., 2009, 2012), North African mineral dust dominates the supply of Fe to much of the study region (Baker et al., 2013; Shelley et al., 2015, 2017; Conway et al., 2018). In addition to the samples classified as European and North American, elevated Fe / Al ratios were also observed in the Marine samples (Fig. 2b). In addition to aerosols derived from continental sources (meaning either mineral dust or anthropogenic emissions), sea spray aerosols could make a relatively higher contribution to the bulk aerosol in remote oceanic locations (de Leeuw et al., 2014). However, this would have the opposite effect as the ratio of $\mathrm{Fe} / \mathrm{Al}$ in surface seawater $(0.017-0.024$ in the North Atlantic gyre, 0.019 European continental shelf, and 0.0300.031 in the Mauritanian upwelling zone; Hatta et al., 2015) is 2 orders of magnitude lower than the crustal ratio. Hence the contribution of sea spray aerosols appears to have a negligible impact on the $\mathrm{Fe} / \mathrm{Al}$ ratios in the bulk Marine aerosols.

The Marine and the High Latitude samples had the widest range in $\mathrm{Fe} / \mathrm{Al}$ ratios and were also collected in the most remote locations. These groups also had the greatest difference in the $\mathrm{Fe} / \mathrm{Al}$ ratios between the total and soluble fractions and contained the samples with the lowest ratios of $\mathrm{Fe} / \mathrm{Al}$ in the soluble fraction (minimum $\mathrm{Fe} / \mathrm{Al}=0.15$, samples G9GA01 and M3-GA03; Fig. 3c), suggesting that even though aerosol Fe is altered towards more soluble forms during atmospheric transport (Longo et al., 2016), atmospheric processing renders $\mathrm{Al}$ even more soluble relative to $\mathrm{Fe}$. However, although the soluble ratio of $\mathrm{Fe} / \mathrm{Al}$ was the same for samples G9-GA01 and M3-GA03, the fractional solubility for Fe differed from $20 \%$ for G9-GA01 to $0.8 \%$ for M3GA03. We suggest that North African mineral dust was contributing to the composition of M3-GA03, resulting in the low solubility of Fe compared to G9-GA01. This suggestion is supported by isotopic evidence (Conway et al., 2018).

For the anthropogenically derived TEs, $\mathrm{Ni}, \mathrm{Cu}, \mathrm{Zn}, \mathrm{Cd}$, and $\mathrm{Pb}$ (Fig. 3e-i) and for at least some of samples of the mixed-source TEs (i.e. with crustal and pollution sources; e.g. $\mathrm{Mn}$ and Co in Fig. $3 \mathrm{~b}$ and d), there is some degree of source-dependence in the elemental ratios, with some significant increases from the UCC mass ratios in the total (Shelley et al., 2015) and UHP water-soluble fractions (Fig. 3). The higher ratios of the UHP water-soluble fraction compared to the total indicates that these TEs are more labile than Al. In addition, studies that have investigated the size distribution of aerosols have found that anthropogenically derived TEs tend to be associated with fine-mode aerosols $(<1 \mu \mathrm{m}$ diameter $)$, which are more soluble than coarse-mode aerosols due to the larger ratio of surface area to volume (Duce et al., 1991; Baker and Jickells, 2006, 2017). Size-fractionated samples were collected during the GA03 cruise, and the smaller size fractions were indeed more soluble than the larger ones for $\mathrm{Al}, \mathrm{Fe}$, and Co (Landing and Shelley, 2013). Enrichment of TEs with predominantly anthropogenic sources accords with other studies in the North Atlantic and is most striking for aerosols that did not originate from the sparsely populated, arid regions of North Africa (e.g. Buck et al., 2010; GeladoCabellero et al., 2012; Patey et al., 2015; Shelley et al., 2015).

\subsection{Aerosol solubility}

\subsubsection{Solubility of aerosol TEs as a function of total concentration: UHP water (instantaneous) compared to $25 \%$ acetic acid leaches}

The UHP water-soluble fraction of aerosol $\mathrm{Fe}$ and $\mathrm{Al}$ determined for all the North Atlantic GA01 and GA03 samples varied by 2 orders of magnitude (Fig. $4 \mathrm{a}$ : $\mathrm{Fe}=0.14$ $21 \%$, median $2.2 \%$; Al $=0.34-28 \%$, median $2.7 \%$ ). Although a broader range of $\mathrm{Fe}$ and $\mathrm{Al}$ solubility was observed in this study, both these results and those reported by Buck et al. (2010) using the same approach $(\mathrm{Fe}=2.9-47 \%$, median $=14 \% ; \mathrm{Al}=3.7-50 \%$, median $=9.5 \%$ ) broadly agree that the median UHP water-soluble fractions of Fe compared to $\mathrm{Al}$ in the North Atlantic are similar. While there was considerable overlap in the ranges of fractional solubility of TEs in aerosols from the different regions (e.g. Fe: European 1.9$21 \%$; North American 0.84-8.8\%; Marine 1.7-18\%; High Latitude dust 1.9-20\%), the North African samples, identified by their orange colour, high $\mathrm{Fe}$ and Al loadings, and definitive AMBTs), formed a distinct cluster of very poorly soluble $\mathrm{Fe}$, or $\mathrm{Al}(<1 \%$; Fig. 4a). However, the solubility of the North African ("Saharan") aerosol Fe was 1-2 orders of magnitude lower in this study $(0.14-0.57 \%)$ than during the Buck et al. (2010) study (2.9-19\%). This supports the hypothesis that TEs from North African aerosols sampled closer to the source (as in this study) are less soluble due to a lesser degree of atmospheric processing and/or larger particle sizes (Baker and Jickells, 2006; Longo et al., 2016).

The inverse relationship between total aerosol loading and fractional solubility has previously been reported for $\mathrm{Fe}$ (Sholkovitz et al., 2009, 2012; Jickells et al., 2016) and Al (Jickells et al., 2016). Jickells et al. (2016) compiled solubility data from the North Atlantic and found that the general trend between $\mathrm{Fe}$ and $\mathrm{Al}$ solubility and atmospheric loading was robust over the range of atmospheric loadings found in the North Atlantic, regardless of the leach protocol employed. In this study, both the UHP soluble and $25 \%$ acetic acid soluble fractions of $\mathrm{Fe}$ and $\mathrm{Al}$ (Fig. 4a and b) were re- 

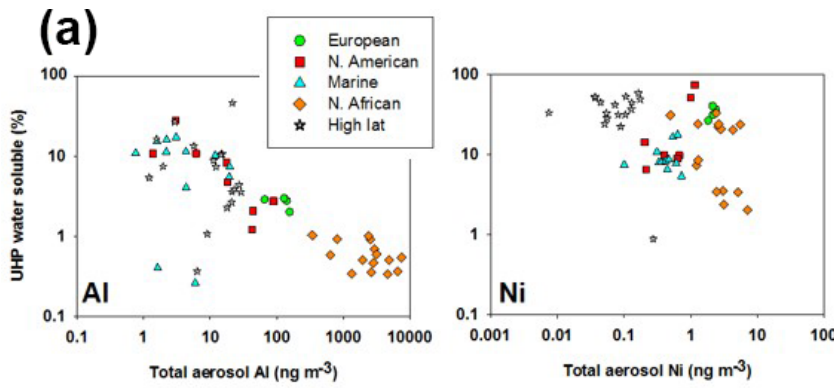

(b)
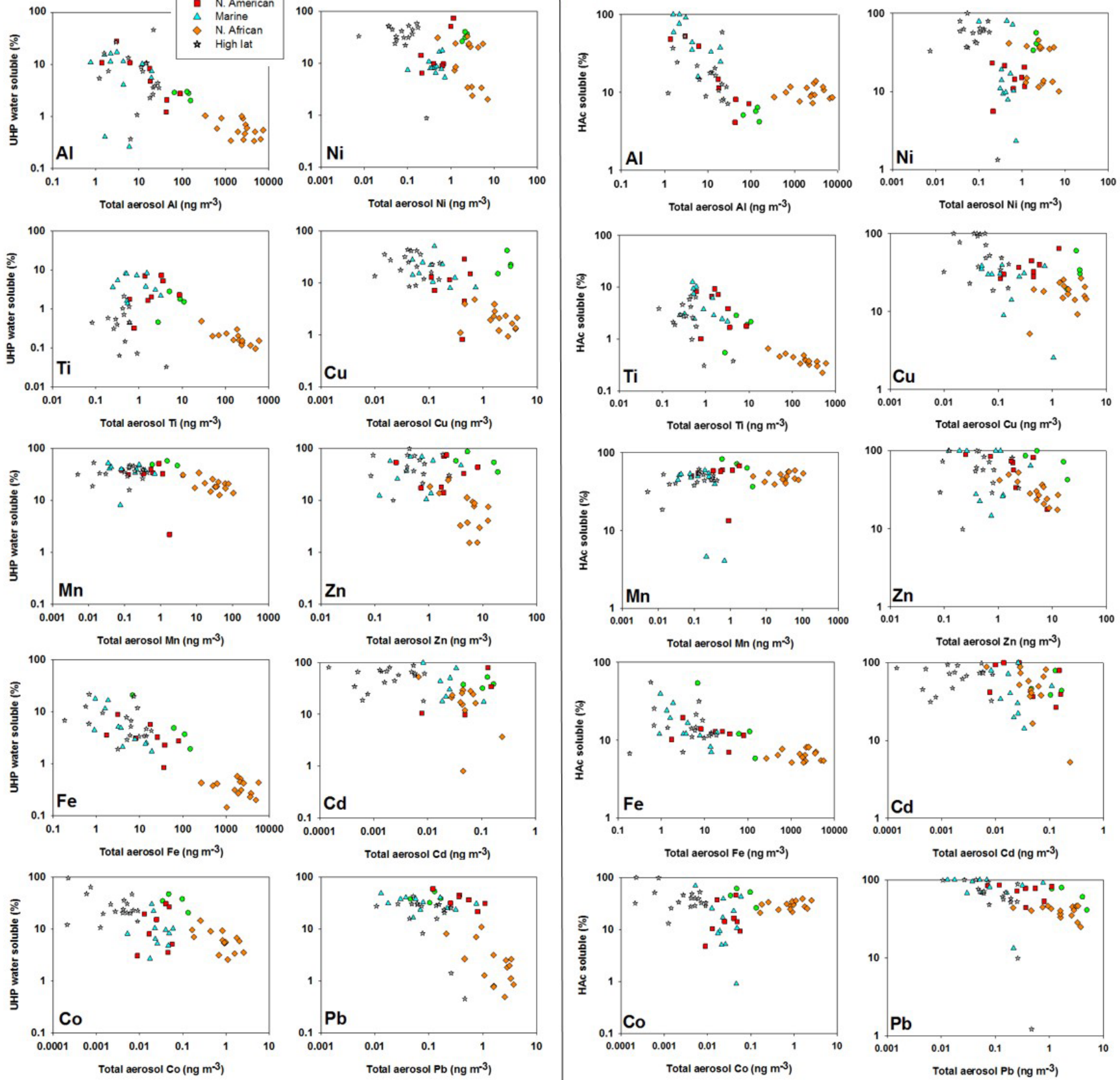

Figure 4. (a) Percentage of UHP water-soluble TE (calculated from Eq. 1) versus total aerosol TE (ng $\mathrm{m}^{-3}$ ); (b) percentage of $25 \%$ acetic acid soluble TE (calculated from Eq. 2) versus total aerosol TE $\left(\mathrm{ng} \mathrm{m}^{-3}\right)$. Data are plotted on $\log -\log$ scales.

lated to atmospheric loading, i.e. the highest loaded North African samples had the lowest solubility. The possible exception to this trend is the fraction of $\mathrm{Al}$ that dissolved from North African aerosols following the $25 \%$ acetic acid leach (Fig. 4b). However, it could simply be that we are observing scatter in our data that is smoothed out in the larger dataset $(n>2000)$ examined by Jickells et al. (2016). Although we cannot rule out that this effect is the result of the heating step in the $25 \%$ acetic acid leach attacking the aluminosilicate matrix, the similarity in the trend of the solubility of $\mathrm{Ti}$ in UHP water and $25 \%$ acetic acid (sharp decrease in solubility with increased aerosol loading; Fig. 4a and b) suggests that matrix attack is minimal. Further experimentation with and without the heating step would help to clarify this issue.

Aluminium, $\mathrm{Ti}$, and $\mathrm{Fe}$ show very similar behaviour in Fig. 4a (sharply decreasing solubility as loading increases). 
Cobalt, $\mathrm{Ni}, \mathrm{Cu}, \mathrm{Zn}$, and $\mathrm{Pb}$ solubilities decrease less strongly as loading increases, whereas $\mathrm{Mn}$ and $\mathrm{Cd}$ show no clear trend. For the acetic acid leaches (Fig. 4b), Ti follows the same trend as the UHP water leach (Fig. 4a), while $\mathrm{Al}$ and Fe plateau at $8-10 \%$ solubility. The other TEs (Mn, Co, Ni, $\mathrm{Cu}, \mathrm{Zn}, \mathrm{Cd}$, and $\mathrm{Pb}$ ) all show almost no trend with loading. The absence of an inverse trend between solubility and loading has previously been noted for Mn (Jickells et al., 2016). For Co the inverse relationship between UHP water solubility and loading was not observed when using the $25 \%$ acetic acid leach, most likely because Co may be associated with the $\mathrm{Mn}$ and Fe oxides that are easily reduced using this leach. For $\mathrm{Zn}$ and $\mathrm{Cd}$, although their average fractional solubilities ( $37 \pm 28$ and $55 \pm 30 \%$ for $\mathrm{Zn}$ and $39 \pm 23$ and $58 \pm 26 \%$ for Cd, for UHP water and $25 \%$ acetic acid leaches, respectively) were similar to Mn $(32 \pm 13$ and $49 \pm 13 \%$ for UHP water and $25 \%$ acetic acid leaches, respectively), the range was greater, with several samples from different regions (although not North Africa) being $100 \%$ soluble after the second leach.

\subsubsection{Solubility of TEs: UHP water (instantaneous) compared to $25 \%$ acetic acid leaches}

All 10 TEs from the five different categories were less soluble in UHP water than $25 \%$ acetic acid (Fig. 5). This is not a surprising finding given the lower $\mathrm{pH}$ of acetic acid compared with UHP water, acetate being a bidentate ligand, the longer contact time of the aerosols with the leach solution, the addition of the hydroxylamine reducing agent, and that the fractional solubility of TEs in $25 \%$ acetic acid was calculated using Eq. (2) (which sums the UHP water and $25 \%$ acetic acid leach concentrations). In addition, there is some degree of source-dependent variability in the relative proportions of each TE that is released by the two leaches. In general, as with the leaches with UHP water, the North African aerosols were distinctly less soluble in $25 \%$ acetic acid compared with aerosols from the other source regions (Fig. 5). Figure 5 highlights the distinction between the lithogenic elements, $\mathrm{Al}, \mathrm{Fe}$, and $\mathrm{Ti}$, which have uniformly low solubility in UHP water (mostly $<20 \%$ ) and extremely low solubility in North African aerosols $(<1 \%)$, and the anthropogenic, pollution-dominated elements, $\mathrm{Ni}, \mathrm{Cu}, \mathrm{Zn}, \mathrm{Cd}$, and $\mathrm{Pb}$, which have solubility up to $100 \%$. Manganese and Co have both lithogenic and anthropogenic sources and so are classified as "mixed source" and have intermediate solubilities. Like all the TEs reported here, Mn solubility in UHP water was significantly less $(p<0.01$, two-tailed, homoscedastic $t$ test) in North African aerosols (median solubility $=19 \%$ ) than in the non-North African samples (median $=38 \%$ ), which seems to contrast somewhat with the findings of Baker et al. (2006b) and Jickells et al. (2016), who found that aerosol source had little impact on Mn solubility. However, in common with these earlier studies (Baker et al., 2006b; Jickells et al., 2016), there was no significant source-dependent differ- ence in Mn solubility in $25 \%$ acetic acid (non-North African samples: $49 \pm 15 \%$, North African samples: $49 \pm 6.4 \%$ ).

\subsubsection{Soluble TEs: UHP water compared to seawater instantaneous leaches}

Seawater leaches were conducted on a subset of samples (GA03-2011) to investigate the suitability of seawater as the leach medium in the instantaneous leach (Fig. 6). During this study, Fe solubility in seawater was lower than in UHP water (Fig. 6c). This phenomenon has previously been observed in atmospheric aerosols from the North Atlantic Ocean (Buck et al., 2010). For Fe, only a few samples of North American and Marine provenance conformed to the relationship described by the equation proposed by Buck et al. (2010), with most of our data plotting above the regression line of the Buck et al. (2010) study (Fig. 6c), indicating that our data were relatively more soluble in UHP water compared to seawater than in this earlier study. One possibility is that the higher aerosol $\mathrm{Fe}$ loadings we observed during GA03-2011 (this study, maximum $=5650 \mathrm{ng} \mathrm{Fe} \mathrm{m}^{-3}$ ), compared to the A16N-2003 transect (Buck et al., 2010; maximum $=1330 \mathrm{n} \mathrm{Fe} \mathrm{m}^{-3}$ ), resulted in a particle concentration effect (Baker and Jickells, 2006), whereby the relationship between aerosol $\mathrm{Fe}$ loading and fractional solubility breaks down because dust on the filter can be a source of soluble $\mathrm{Fe}$ but can also scavenge dissolved $\mathrm{Fe}$ from the seawater leach solution as it passes through the filter. Given that the link between Fe solubility in seawater and Fe-binding ligand availability is well established (e.g. Rue and Bruland, 1995; Gledhill and Buck, 2012), an alternative explanation for the difference in Fe solubility is that the organic composition of the seawater used as the leach mediums differed between the two studies.

Manganese is the only TE that had a slope close to unity (0.98; Fig. 6b), suggesting that solubility estimates were not impacted by the choice of leach medium used. This is consistent with other studies that have found that Mn solubility is less sensitive to the choice of leach media or to aerosol provenance than other TEs (Baker et al., 2006b; Jickells et al., 2016). Due to the large variability in the dataset, there was no significant difference between Mn solubility in UHP water or seawater (32 \pm 13 and $24 \pm 17 \%$, respectively; Fig. S3 and Tables S3 and S4 in the Supplement). Table S5 shows which regions had slopes for UHP water versus seawater fractional solubility that did not differ significantly from 1.0 at the $95 \%$ confidence level ( $t$ statistic).

Lead was the only TE with all slopes differing significantly from 1.0 and the only TE where the solubility in seawater was higher than in UHP water for virtually every sample (Fig. 6i). As for Pb, most of the Co data fall below the 1:1 line (Fig. 6d), indicating that Co was also generally more soluble in seawater than UHP water. In contrast, the opposite trend was observed for $\mathrm{Fe}$ and $\mathrm{Ni}$ (Fig. $6 \mathrm{c}$ and e), perhaps due to differences in the availability of metal binding 

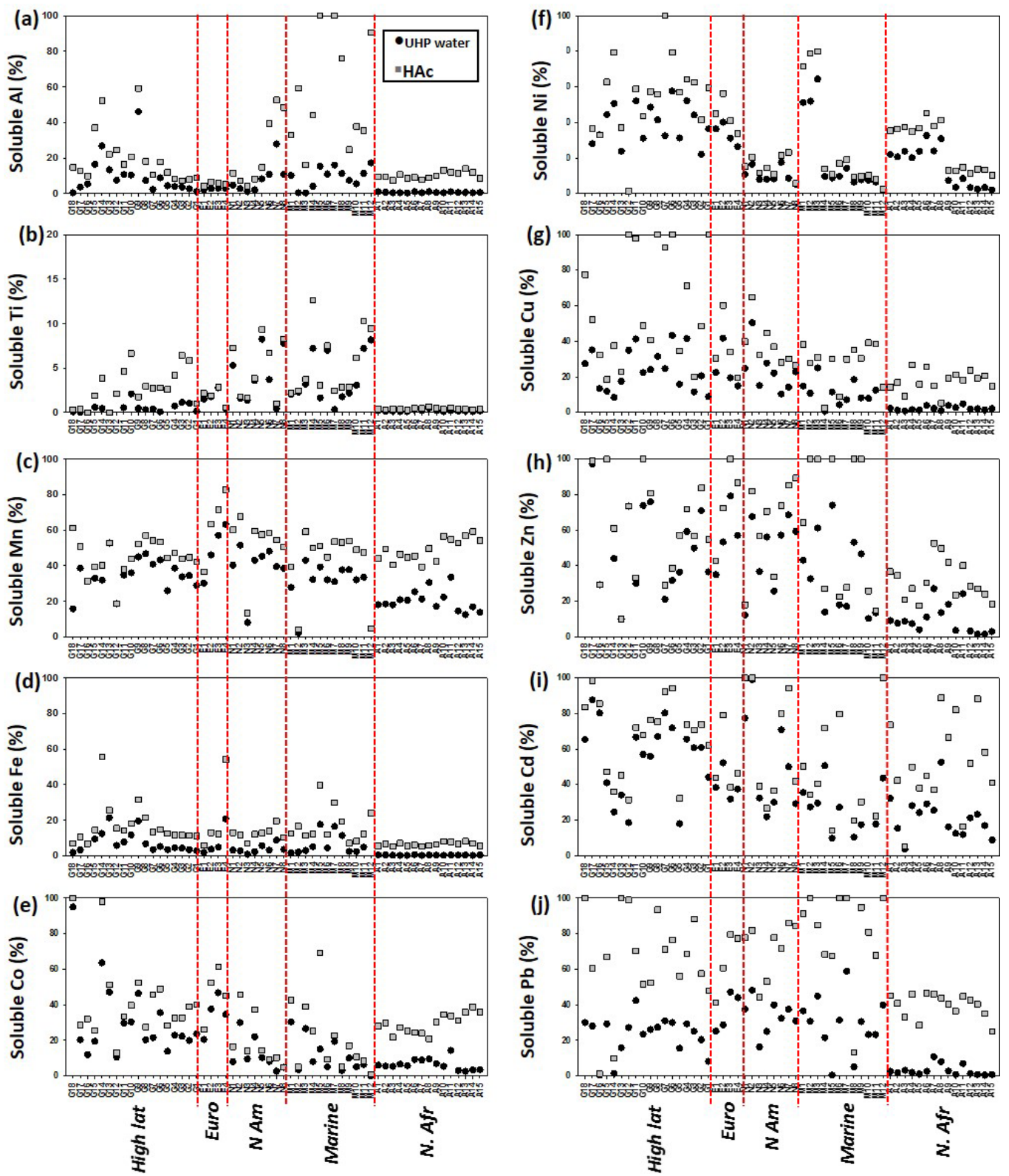

Figure 5. Solubility of $\mathrm{Al}, \mathrm{Ti}, \mathrm{Mn}, \mathrm{Fe}, \mathrm{Co}, \mathrm{Ni}, \mathrm{Cu}, \mathrm{Zn}, \mathrm{Cd}$, and $\mathrm{Pb}$ following a UHP water leach (UHP water, black circles, calculated using Eq. 1) and a sequential leach of $25 \%$ acetic acid (HAc, grey squares, calculated using Eq. 2). The red vertical dashed lines represent the different aerosol source categories, as labelled in panel (b). Note that Ti (panel b) is highly insoluble and has a maximum value of $<13 \%$. The data for this figure are also presented in Fig. S4 as biplots of UHP water fractional solubility versus $25 \%$ acetic acid fractional solubility.

ligands in the seawater used. A challenge of using seawater as the leach medium is that it is difficult to control for natural variability in the types and concentrations of organic ligands. Consequently, it is not possible to determine conclusively why contrasting trends in the fractional solubility of TEs were observed. For this reason, we advocate for the use of UHP water as a common leach medium to facilitate comparisons of solubility resulting from differences in aerosol composition. An additional benefit is the ease of analysis of UHP water compared to seawater.

\subsection{Visualising marine aerosol sources using multivariate statistical approaches}

As the PMF analysis was only able to identify two significant factors accounting for the total aerosol TE concentrations, another multivariate approach was taken. Hierarchical cluster analysis (Ward's method, Euclidian distance) was performed using the R statistical package (v. 3.3.0; R Core Team, 2016) to look for trends in the data that might reveal the various aerosol sources. Hierarchical cluster analysis was performed 

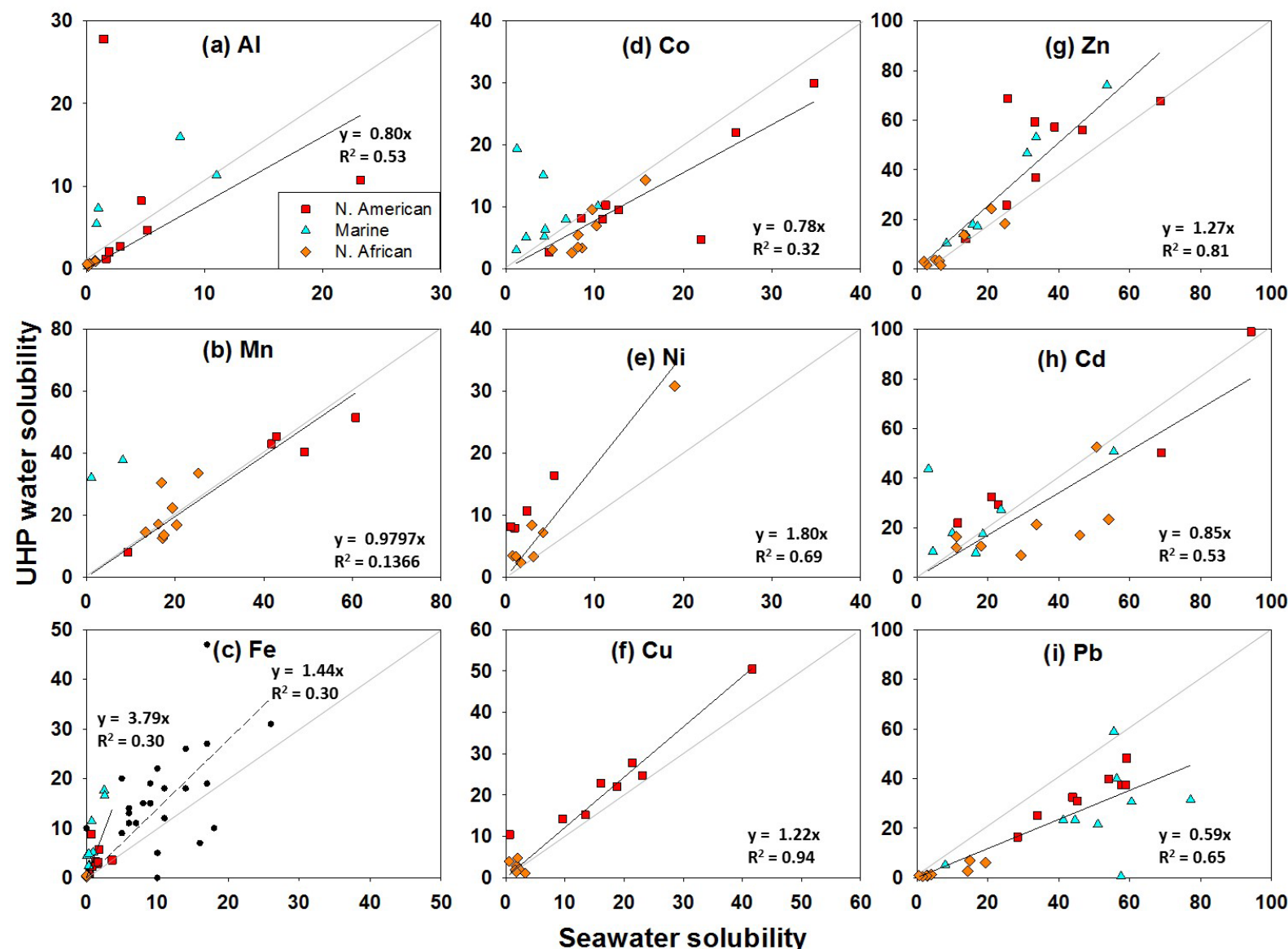

Figure 6. Comparison of TE solubility following instantaneous leaches using UHP water or locally collected, filtered seawater. The solid line is the 1:1 line. Where fewer data are observed, concentrations were below detection for one or both of the two leaches. The data for soluble aerosol Fe from within our study region from Buck et al. (2010) are plotted as black circles in panel (c).

on (1) log-transformed total aerosol TE plus $\mathrm{NO}_{3}^{-}$concentration data (Fig. 7a) and (2) log-transformed TE fractional solubility plus $\mathrm{NO}_{3}^{-}$concentration data (Fig. 7b). The $\mathrm{NO}_{3}^{-}$ concentrations appear in both runs as we wanted to include TEs plus an indicator of anthropogenic pollution.

Figure 7 a shows two main branches to the dendrogram of the total TE concentration data. One branch groups all the North African and European samples and two North American samples (N2 and N4) together, and the other branch groups all other samples together. Samples closest to each other are the most similar to each other, and those joined in the same groups share similar characteristics. Therefore, in this analysis, the North African samples are grouped together, as are the High Latitude samples. All but three North African samples form a distinct sub-group. The three remaining North African samples (A8, A9, and A11) share more characteristics with the European samples, lending support for mixing of aerosols from the two regions. Counterintuitively, the two European samples with the lowest $\mathrm{Fe} / \mathrm{Al}$ ratios (E3 and E4) are the ones that are most similar to the two North American samples, which have relatively high $\mathrm{Fe} / \mathrm{Al}$ ratios of 0.90 and 0.87 . The GA01 samples (with the exception of one sample, G15) form a distinct cluster, but with three sub-groups: one is the Greenland/Labrador Sea samples (without G15), and the other two are related to each other but distinct from the Greenland/Labrador Sea samples and are a mixture geographically of the other samples. However, there is a trend: the "middle" group is the group of samples collected closest to land and the group to the right is the group of samples collected furthest from land. The other groupings are made up of a mixture of North American and Marine samples. This suggests that the Marine samples are comprised predominantly of North American aerosols from more than one source. The only anomaly is the two North American samples that "look European".

Although there are differences between Fig. 7a (total TEs) and b (25\% acetic acid fractional solubility; Eq. 2$)$, the general trend of an inverse relationship between TE atmospheric loading and fractional solubility holds, as the North African samples with the highest concentrations and lowest fractional solubilities appear on the left in Fig. 7a and on the right in Fig. 7b. In terms of fractional solubility, the North 


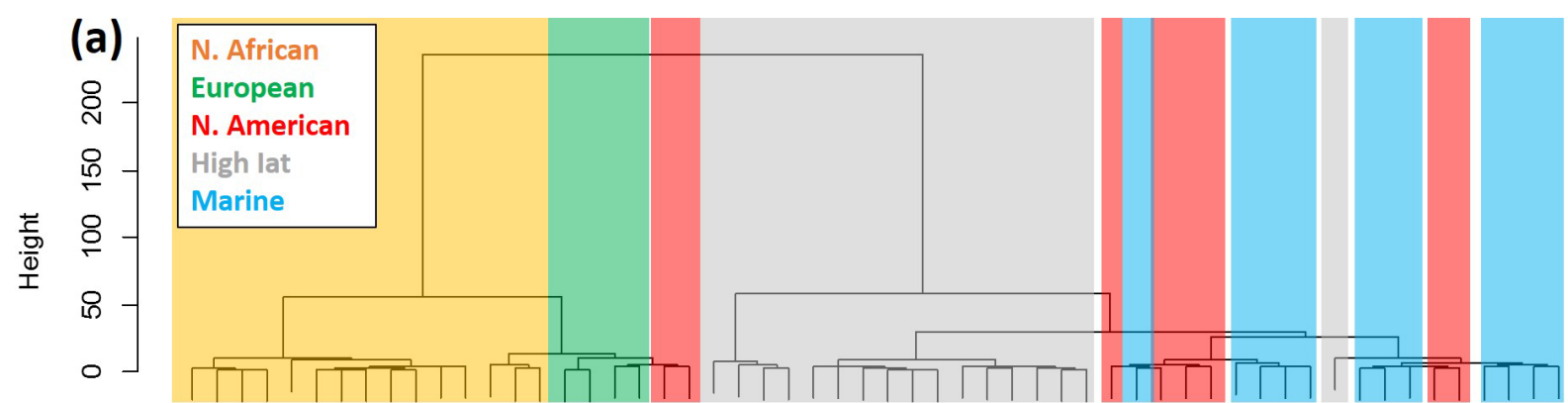

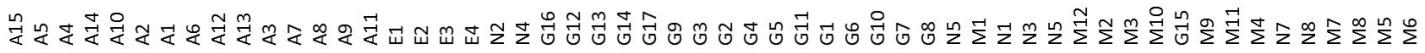

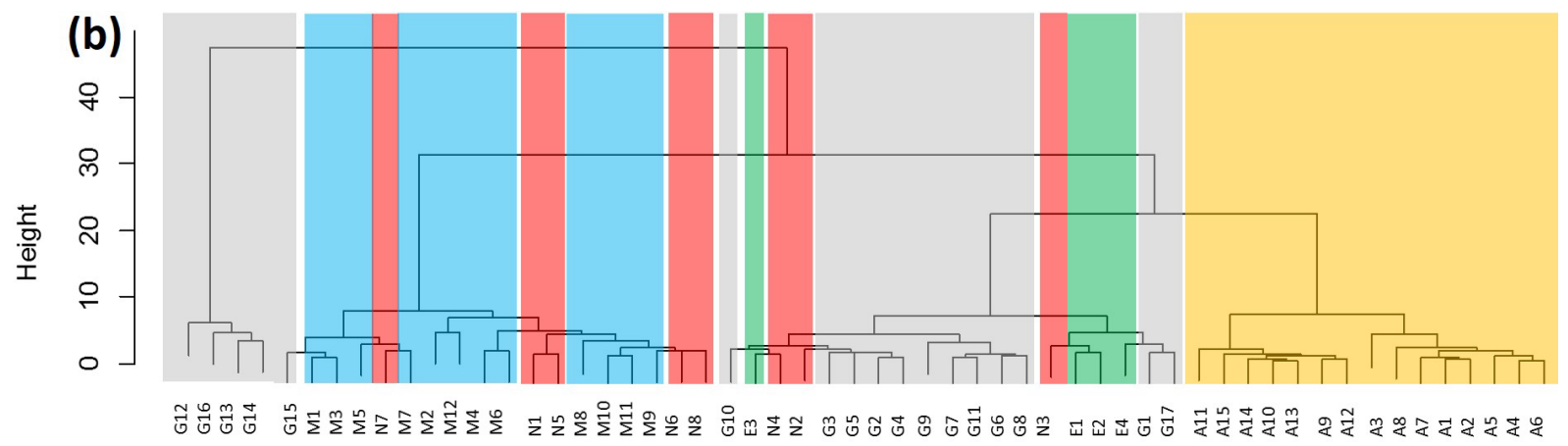

Figure 7. Hierarchical cluster analysis of (a) log-transformed total TE concentration data plus $\mathrm{NO}_{3}^{-}$concentration data and (b) logtransformed fractional solubility following the two-step sequential leach (fractional solubility calculated using Eq. 2) plus $\mathrm{NO}_{3}^{-}$concentration data. The coloured blocks correspond to the aerosol source regions shown in the legend (note that the North African samples correspond to the yellow blocks of colour).

African samples form a distinct cluster, but this cluster is made up of two sub-groups: one collected during GA03-2010 and one during GA03-2011. The samples collected from near Greenland and the Labrador Sea are also distinct from the other GA01 samples (again with the exception of G15) and also distinct from all other samples. The European samples, all other GA01 samples, and three North American samples form a loose cluster. The remaining North American samples and all the Marine samples form another loose cluster.

Plotting the data this way still does not allow us to identify the aerosol sources definitively, but it does allow us to visualise which samples have the most similar physicochemical characteristics and confirms the general trend of a relationship between aerosol loading and fractional solubility and, by extension, bioavailability, even though we have demonstrated that this relationship is not present for all TEs. This knowledge is then useful as a general rule of thumb in biogeochemical models, although clearly other factors also exert controls on aerosol TE solubility. For example, during their investigations of the GA03 aerosols, Wozniak et al. (2013, 2014, 2015) proposed a role for water-soluble organic carbon in controlling the solubility of Fe. Desboeufs et al. (2005) also found evidence for a link between total carbon and TE solubility in regions impacted by anthropogenic activity. Thus, the carbon content of aerosols is also implicated as a control on aerosol Fe solubility, but the relationship is frequently not linear.

\subsection{Choice of leach and modelling TE solubility}

The ability of models to replicate subtleties in aerosol TE solubility may prove critical in forecasting ecosystem impacts and responses. Due to the magnitude of North African dust inputs to the North Atlantic region (very high dust inputs result in a high soluble TE aerosol flux despite relatively low fractional solubility), this is a particular challenge and is compounded by additional unknowns such as how aerosol acidity will be impacted by the combined effects of increasing industrialisation and urbanisation, as well as changes in the magnitude of future mineral dust supply and biomass burning (Knippertz et al., 2015; Weber et al., 2016). In other words, it is important to accurately constrain aerosol TE solubility with high-quality data in order to improve the predictive capacity of models. Clearly the choice of leach media and protocol impacts the measured fractional solubility. This is shown in both Figs. 4 and 5 and has a number of implications with regard to modelling the impact of atmospheric deposition on marine biogeochemistry. For example, for elements with generally low solubility, such as Fe, the difference between 1 and $2 \%$ solubility is an increase of $100 \%$, 
meaning that only half the amount of dust is needed to yield the same amount of dissolved Fe. To complicate matters further, recent research has demonstrated that some diazotrophs are able to directly access particulate Fe (Rubin et al., 2011). The significance of this is that Trichodesmium is common in the North Atlantic gyre under the influence of the Saharan plume, and the North African dust samples have higher fractional solubility for Fe using the acetic acid leach. If Trichodesmium is able to access the acetic acid soluble fraction of the aerosol Fe, as the study indicates (Rubin et al., 2011), our data suggest that 20 -fold more aerosol $\mathrm{Fe}$ is available for uptake than is suggested from the instantaneous UHP water leach. This suggests that in regions where Trichodesmium proliferate, we are likely to underestimate bioavailable Fe using the instantaneous UHP water leaching method.

There are implications for modelling the impact of atmospheric deposition for other TEs. Although the lack of source-dependent differences in Mn solubility in these aerosols makes modelling $\mathrm{Mn}$ solubility simpler, there was still a difference in the fractional solubility calculated from the two leaches (UHP water: $32 \pm 13$ and $25 \%$; acetic acid: $49 \pm 13 \%$ ). However, for $\mathrm{Al}$, there was a large range in solubility: 0.3-28\% using UHP water and 4.1-100\% using $25 \%$ acetic acid. Both ranges far exceed the relatively narrow range used in the MADCOW model (1.5-5\%), which has been used to estimate atmospheric inputs based on dissolved $\mathrm{Al}$ concentrations in the mixed layer (Measures and Brown, 1996). It is noted, however, that the median values from this study fall within the range used by the MADCOW model (2.7 and $3.3 \%$ for UHP water and $25 \%$ acetic acid, respectively). We highlight this issue to draw attention to some of the problems inherent in modelling TE solubility and its impact on the chemistry and biogeochemistry of the upper ocean.

Given that the different leaching approaches access different fractions of aerosol TEs that can dissolve from aerosols at different rates (e.g. TEs loosely bound to surfaces and TEs that are associated with less reactive phases) (e.g. Koçak et al., 2007; Mackey et al., 2015), we need to conduct experiments that elucidate the relationship between the soluble and bioavailable fractions. In the meantime, we suggest that the $25 \%$ acetic acid leach might be better to estimate the bioavailable fraction given that $\mathrm{Fe}$ (and perhaps other TEs) associated with lithogenic particles are directly available to micro-organisms in productive regions and regions with high dust inputs (Rubin et al., 2011) and that aerosol particles can be processed by zooplankton (Schmidt et al., 2016).

\section{Conclusions}

Aerosol TE solubility is usually determined using operationally defined methods, while biogeochemical models require robust relationships between two or more parameters that can be used to predict TE solubility in order to constrain the bioavailable fraction of aerosol TEs. In this study, we used a two-stage leach (UHP water followed by $25 \%$ acetic acid with hydroxylamine hydrochloride) to investigate the fractional solubility of a suite of trace elements (Al, Ti, Mn, $\mathrm{Fe}, \mathrm{Co}, \mathrm{Ni}, \mathrm{Cu}, \mathrm{Zn}, \mathrm{Cd}, \mathrm{Pb}$ ) from aerosols collected in the North Atlantic during three GEOTRACES research cruises (GA03-2010, GA03-2011, and GA01). Five regions were identified based on AMBT simulations; (i) North Africa, (ii) Europe, (iii) North America, (iv) High Latitude, and (v) Marine. However, the AMBTs were not able to sufficiently discriminate aerosol sources within these regions. Of these five categories, the North African aerosols were the most homogeneous in terms of their fractional solubility and elemental ratios. In contrast, samples from the most remote locations, the Marine and High Latitude aerosols, had the most spread in their fractional solubility and elemental ratios. Elemental ratios were discussed rather than enrichment factors normalised to UCC composition since earlier work highlighted that the UCC ratios are not representative of the North African mineral dust end member, which dominates aerosol supply in much of the study area.

We observed an inverse relationship between the fractional solubility of $\mathrm{Al}, \mathrm{Ti}, \mathrm{Fe}, \mathrm{Ni}, \mathrm{Cu}$, and $\mathrm{Pb}$ and aerosol loading for all leach media (UHP water, filtered seawater, and $25 \%$ acetic acid with hydroxylamine hydrochloride). However, $\mathrm{Mn}, \mathrm{Zn}$, and Cd fractional solubility appears to be independent of atmospheric loading. For Co, the inverse relationship between UHP water solubility and loading was not observed when using the $25 \%$ acetic acid leach, most likely because Co may be associated with the $\mathrm{Mn}$ and Fe oxides that are easily reduced using the $25 \%$ acetic acid leach. Further work is required to assess exactly which fraction is accessed by the various leach protocols in order to understand links between the soluble and bioavailable fractions.

Data availability. Data are available at BCO-DMO (GA03; www. bco-dmo.org) and LEFE-CYBER (GA01; https://www.bodc.ac. uk/geotraces/data/inventories/geovide/; Shelley and Sarthou, 2018) and on request from the lead author.

\section{The Supplement related to this article is available online at https://doi.org/10.5194/bg-15-2271-2018-supplement.}

Competing interests. The authors declare that they have no conflict of interest.

Special issue statement. This article is part of the special issue "GEOVIDE, an international GEOTRACES study along the OVIDE section in the North Atlantic and in the Labrador Sea (GA01)". It is not associated with a conference. 
Acknowledgements. Many thanks to the captains and crews of the R/V Knorr (GA03-2010 and 2011) and N/O Pourquoi Pas? (GA01); the chief scientists (GA03: Bob Anderson, Ed Boyle, and Greg Cutter; GA01: Geraldine Sarthou and Pascale Lherminier); Alex Baker for the loan of the aerosol sampler used on GA01; and Alina Ebling Petroc Shelley, Alex Landing, and Sarah Huff for their help with sample processing and analysis. This work was supported by grants to WML (NSF-OCE 0752832, 0929919, and 1132766) and GS (ANR-13-B506-0014 and ANR-12-PDOC-0025-01). RUS was supported by a LabexMER International Postdoctoral Fellowship and CG29 Postdoctoral Fellowship. A portion of this work was performed at the National High Magnetic Field Laboratory, which is supported by National Science Foundation Cooperative Agreement No. DMR-1157490 and the state of Florida. The aerosol digestions for GA01 were undertaken in the geochemistry clean room at Ifremer (Centre de Bretagne). Trace element determination for GA01 was conducted at the Pôle de Spectrométrie Océan at the Institut Universitaire Européen de la Mer with the support and guidance of Claire Bollinger and Marie-Laure Rouget. Finally, we thank Karine Desbeoufs and an anonymous reviewer for their critiques, which have contributed to the improvement of the manuscript.

Edited by: Gilles Reverdin

Reviewed by: Karine Desboeufs and one anonymous referee

\section{References}

Achterberg, E. P., Moore, C. M., Henson, S. A., Steigenberger, S., Stohl, A., Eckhardt, S., Avendano, L. C., Cassidy, M., Hembury, D., Klar, J. K., Lucas, M. I., Macey, A. I., Marsay, C. M., and Ryan-Keogh, T. J.: Natural iron fertilization by the Eyjafjallajökull volcanic eruption, Geophys. Res. Lett., 40, 921-926, https://doi.org/10.1002/grl.50221, 2013.

Adams, A. M., Prospero, J. M., and Zhang, C.: CALIPSODerived Three-Dimensional Structure of Aerosol over the Atlantic Basin and Adjacent Continents, J. Climate, 25, 6862-6879, https://doi.org/10.1175/JCLI-D-11-00672.1, 2012.

Aguilar-Islas, A. M., Wu, J., Rember, R., Johansen, A. M., and Shank, L. M.: Dissolution of aerosol-derived iron in seawater: Leach solution chemistry, aerosol type, and colloidal iron fraction, Mar. Chem., 120, 25-33, 2010.

Arnalds, O.: Soils of Iceland, Jökull, 58, 409-421, 2004.

Baker, A. R. and Croot, P. L.: Atmospheric and marine controls on aerosol iron solubility in seawater, Mar. Chem., 120, 4-13, 2010.

Baker, A. R. and Jickells, T. D.: Mineral particle size as a control on aerosol iron solubility., Geophys. Res. Lett., 33, L17608, https://doi.org/10.1029/2006GL026557, 2006.

Baker, A. R. and Jickells, T. D.: Atmospheric deposition of soluble trace elements along the Atlantic Meridional Transect (AMT), Prog. Oceanogr., 158, 41-51, https://doi.org/10.1016/j.pocean.2016.10.002, 2017.

Baker, A. R., Jickells, T. D., Biswas, K. F., Weston, K., and French, M.: Nutrients in atmospheric aerosol particles along the Atlantic Meridional Transect, Deep-Sea Res. Pt II, 53, 1706-1719, 2006 a.

Baker, A. R., Jickells, T. D., Witt, M., and Linge, K. L.: Trends in the solubility of iron, aluminium, manganese and phosphorus in aerosol collected over the Atlantic Ocean, Mar. Chem., 98, 4358, 2006b.

Baker, A. R., Adams, C., Bell, T. G., Jickells, T. D., and Ganzeveld, L.: Estimation of atmospheric nutrient inputs to the Atlantic Ocean from $50^{\circ} \mathrm{N}$ to $50^{\circ} \mathrm{S}$ based on large-scale filed sampling: Iron and other dust-associated elements, Global Biogeochem. Cy., 27, 755-767, https://doi.org/10.1002gbc.20062, 2013.

Baker, A. R., Landing, W. M., Bucciarelli, E., Cheize, M., Fietz, S., Hayes, C. T., Kadko, D., Morton, P. L., Rogan, N., Sarthou, G., Shelley, R. U., Shi, Z., Shiller, A., and van Hulten, M. M. P.: Trace element and isotope deposition across the air-sea interface: progress and research needs, Philos. T. R. Soc. A, 374, 20160190, https://doi.org/10.1098/rsta.2016.0190, 2016.

Baratoux, D., Mangold, N., Arnalds, O., Bardintzeff, J.-M., Platevoët, B., Grégoire, M., and Pinet, P.: Volcanic sands of Iceland - Diverse origins of aeolian sand deposits revealed at Dyngjusandur and Lambahraun, Earth Surf. Processes, 36, 1789-1808, https://doi.org/10.1002/esp.2201, 2011.

Ben-Ami, Y., Koren, I., Rudich, Y., Artaxo, P., Martin, S. T., and Andreae, M. O.: Transport of North African dust from the Bodélé depression to the Amazon Basin: a case study, Atmos. Chem. Phys., 10, 7533-7544, https://doi.org/10.5194/acp10-7533-2010, 2010.

Berger, J. M., Lippiatt, S. M., Lawrence, M. G., and Bruland, K. W.: Application of a chemical leach technique for estimating labile particulate aluminum, iron, and manganese in the Columbia River plume and coastal waters off Oregon and Washington, J. Geophys. Res., 113, C00B01, https://doi.org/10.1029/2007JC004703, 2008.

Bridgestock, L., Rehkämper,M., van de Flierdt,T., Murphy, K., Khondoker, R., Baker, A. R., Chance, R., Strekopytov, S., Humphreys-Williams, E., and Achterberg E. P.: The Cd isotope composition of atmospheric aerosols from the Tropical Atlantic Ocean, Geophys. Res. Lett., 44, 2932-2940, https://doi.org/10.1002/2017GL072748, 2017.

Buck, C. S., Landing, W. M., Resing, J. A., Lebon, G. T.: Aerosol iron and aluminum solubility in the northwest Pacific Ocean: Results from the 2002 IOC cruise, Geochem. Geophy. Geosy., 7, Q04M07, https://doi.org/10.1029/2005GC000977, 2006.

Buck, C. S., Landing, W. M., Resing, J. A., and Measures, C. I.: The solubility and deposition of aerosol $\mathrm{Fe}$ and other trace elements in the North Atlantic Ocean: Observations from the A16N CLIVAR/ $/ \mathrm{CO}_{2}$ repeat hydrography section., Mar. Chem., 120, 57-70, 2010

Bullard, J. E., Baddock, M., Bradwell, T., Crusius, J., Darlington, E., Gaiero, D., Gassó, S., Gisladottir, G., Hodgkins, R., McCulloch, R., McKenna-Neuman, C., Mockford, T., Stewart, H., and, Thorsteinsson, T.: High-latitude dust in the Earth system, Rev. Geophys., 54, 447-485, https://doi.org/10.1002/2016RG000518, 2016.

Cheize, M., Sarthou, G., Croot, P., Bucciarelli, E., Baudoux, A.-C., and Baker, A.: Iron organic speciation determination in rainwater using cathodic stripping voltammetry, Anal. Chim. Acta, 726, 45-54, 2012.

Chiapello, I., Bergametti, G., Chatenet, B., Bousquet, P., Dulac, F., and Soares, E. S.: Origins of African dust transported over the northeastern tropical Atlantic, J. Geophys. Res.-Atmos., 102, 13701-13709, https://doi.org/10.1029/97jd00259, 1997. 
Chueinta, W., Hopke, P. K., and Paatero, P.: Investigation of sources of atmospheric aerosol at urban and suburban residential areas in Thailand by positive matrix factorization, Atmos. Environ., 34, 3319-3329, https://doi.org/10.1016/S1352-2310(99)00433$1,2000$.

Conway, T. M. and John, S. G.: Quantification of dissolved iron sources to the North Atlantic Ocean, Nature, 511, 212-215, https://doi.org/10.1038/nature13482, 2014.

Conway, T. M., Shelley, R. U., Aguilar-Islas, A. M., Landing, W. M., Mahowald, N. M., and John, S. G.: Iron isotopes reveal and important anthropogenic aerosol iron flux to the North Atlantic, Nat. Commun., under review, 2018.

de Leeuw, G., Guieu, C., Arneth, A., Bellouin, N., Bopp, L., Boyd, P. W., Denier van der Gon, H. A. C., Desboeufs, K. V., Dulac, F., Facchini, M. C., Gantt, B., Langmann, B., Mahowald, N. M., Maranon, E., O’Dowd, C., Olgun, N., Pulido-Villena, E., Rinaldi, M., Stephanou, E. G., and Wagener, T.: Ocean-atmosphere interactions of particles, in: Ocean-atmosphere interactions of gases and particles, edited by: Liss, P. S. and Johnson, M. T., SpringerVerlag, Berlin, 171-245, 2014.

Desboeufs, K. V., Sofikitis, A., Losno, R., Colin, J. L., and Ausset, P.: Dissolution and solubility of trace metals from natural and anthropogenic aerosol particulate matter, Chemosphere, 58, 195203, 2005.

Doherty, O. M., Riemer, N., and Hameed, S.: Role of the convergence zone over West Africa in controlling Saharan mineral dust load and transport in the boreal summer, Tellus B, 66, 1, https://doi.org/10.3402/tellusb.v66.23191, 2014.

Duce, R. A., Liss, P. S., Merrill, J. T., Atlas, E. L., Buat-Menard, P., Hicks, B. B., Miller, J. M., Prospero, J. M., Arimoto, R., Church, T. M., Ellis, W., Galloway, J. N., Hansen, L., Jickells, T. D., Knap, A. H., Reinhardt, K. H., Schneider, B., Soudine, A., Tokos, J. J., Tsunogai, S., Wollast, R., and Zhou, M.: The atmospheric input of trace species to the world ocean, Global Biogeochem. Cy., 5, 193-259, https://doi.org/10.1029/91gb01778, 1991.

Fishwick, M. P., Sedwick, P. N., Lohan, M. C., Worsfold, P. J., Buck, K. N., Church, T. M., and Ussher, S. J.: The impact of changing surface ocean conditions on the dissolution of aerosol iron, Global Biogeochem. Cy., 28, 1235-1250, https://doi.org/10.1002/2014GB004921, 2014.

Formenti, P., Schütz, L., Balkanski, Y., Desboeufs, K., Ebert, M., Kandler, K., Petzold, A., Scheuvens, D., Weinbruch, S., and Zhang, D.: Recent progress in understanding physical and chemical properties of African and Asian mineral dust, Atmos. Chem. Phys., 11, 8231-8256, https://doi.org/10.5194/acp11-8231-2011, 2011.

Gelado-Caballero, M. D., López-García, P., Prieto, S., Patey, M. D., Collado, C., and Hérnández-Brito, J. J.: Long-term aerosol measurements in Gran Canaria, Canary Islands: Particle concentration, sources and elemental composition, J. Geophys. Res.Atmos., 117, D03304, https://doi.org/10.1029/2011jd016646, 2012.

GEOTRACES Planning Group: GEOTRACES Science Plan, Baltimore, Maryland: Scientific Committee on Oceanic Research, available at: http://www.geotraces.org/science/science-plan (last access: 13 April 2018), 2006.

Gledhill, M. and Buck, K. N.: The organic complexation of iron in the marine environment: a review, Front. Microbiol., 3, 69, https://doi.org/10.3389/fmicb.2012.00069, 2012.
Guieu, C., Loye-Pilot, M.-D., Ridame, C., and Thomas, C.: Chemical characterization of the Saharan dust end-member: Some biogeochemical implications for the western Mediterranean Sea, J. Geophys. Res., 107, ACH 5-1-ACH 5-11, https://doi.org/10.1029/2001JD000582, 2002.

Hatta, M., Measures, C. I., Wu, J., Roshan, S., Fitzsimmons, J. N., Sedwick, P., and Morton, P.: An overview of dissolved Fe and Mn Distributions during the 2010-2011 U.S. GEOTRACES north Atlantic Cruises: GEOTRACES GA03, Deep-Sea Res. Pt II, 116, 117-129, https://doi.org/10.1016/j.dsr2.2014.07.005, 2015.

Helmers, E. and Schrems, O.: Wet deposition of metals to the tropical North and the South Atlantic Ocean, Atmos. Environ., 29, 2475-2484, 1995.

Jickells, T. D., Baker, A. R., and Chance, R.: Atmospheric transport of trace elements and nutrients to the oceans, Philos. T. R. Soc. A, 374, 20150286, https://doi.org/10.1098/rsta.2015.0286, 2016.

Johansen, A., Siefert, R. L., and Hoffmann, M. R.: Chemical composition of aerosols collected over the tropical North Atlantic Ocean, J. Geophys. Res., 105, 15277-15312, 2000.

Johnson, B. T., Osborne, S. R., Haywood, J. M., and Harrison, M. A. J.: Aircraft measurements of biomass burning aerosol over West Africa during DABEX, J. Geophys. Res., 113, D00C06, https://doi.org/10.1029/2007JD009451, 2008.

Kim, G., Alleman, L. Y., and Church, T. M.: Atmospheric depositional fluxes of trace elements, $210 \mathrm{~Pb}$, and $7 \mathrm{Be}$ to the Sargasso Sea, Global Biogeochem. Cy., 13, 1183-1192, https://doi.org/10.1029/1999gb900071, 1999.

Knippertz, P., Coe, H., Chiu, J. C., Evans, M. J., Fink, A. H., Kalthoff, N., Liousse, C., Mari, C., Allan, R. P., Brooks, B., Danour, S., Flamant, C., Jegede, O. O., Lohou, F., and, Marsham, J. H.: The DACCIWA Project: Dynamics-AerosolChemistry-Cloud Interactions in West Africa, B. Am. Meteorol. Soc., 96, 1451-1460, https://doi.org/10.1175/BAMS-D-14$00108.1,2015$.

Koçak, M., Kubilay, N., Herut, B., and Nimmo, M.: Trace Metal Solid State Speciation in Aerosols of the Northern Levantine Basin, East Mediterranean, J. Atmos. Chem., 56, 239-257, https://doi.org/10.1007/s10874-006-9053-7, 2007.

Lafon, S., Sokolik, I. N., Rajot, J. L., Caquineau, S., and Gaudichet, A.: Characterization of iron oxides in mineral dust aerosols: Implications for light absorption, J. Geophys. Res., 111, D21207, https://doi.org/10.1029/2005JD007016, 2006.

Laing, J. R., Hopke, P. K., Hopke, E. F., Husain, L., Dutkiewicz, V. A., Paatero, J., and Viisanen, Y.: Positive Matrix Factorization of 47 Years of Particle Measurements in Finnish Arctic, Aerosol Air Qual. Res., 15, 188-207, https://doi.org/10.4209/aaqr.2014.04.0084, 2015.

Landing, W. M. and Shelley, R. U.: Particle size effects on aerosol iron solubility from the U.S. GEOTRACES North Atlantic Zonal Transect (2010, 2011), ASLO 2013 Aquatic Sciences Meeting, 20 February 2013, New Orleans, USA, 2013.

Longhurst, A.: Ecological Geography of the Sea, Academic Press, San Diego, CA, USA, 1998.

Longo, A. F., Feng, Y., Lai, B., Landing, W. M., Shelley, R. U., Nenes, A., Mihalopoulos, N., Violaki, K., and, Ingall, E. D.: Influence of Atmospheric Processes on the Solubility and Composition of Iron in Saharan Dust, Environ. Sci. Technol., 50, 69126920, https://doi.org/10.1021/acs.est.6b02605, 2016. 
Mackey, K. R. M., Chien, C.-T., Post, A. F., Saito, M. A., and Paytan, A.: Rapid and gradual modes of aerosol trace metal dissolution in seawater, Front. Microbiol., 5, 1-11, https://doi.org/10.3389/fmicb.2014.00794, 2015.

Maring, H., Settle, D. M., Buat-Ménard, P., Dulac, F., and Patterson, C. C.: Stable lead isotopes tracers of air mass trajectories in the Mediterranean region, Nature, 300, 154-156, 1987.

Marticorena, B., Chatenet, B., Rajot, J. L., Traoré, S., Coulibaly, M., Diallo, A., Koné, I., Maman, A., NDiaye, T., and Zakou, A.: Temporal variability of mineral dust concentrations over West Africa: analyses of a pluriannual monitoring from the AMMA Sahelian Dust Transect, Atmos. Chem. Phys., 10, 8899-8915, https://doi.org/10.5194/acp-10-8899-2010, 2010.

McConnell, C. L., Highwood, E.J., Coe, H., Formenti, P., Anderson, B., Osborne, S., Nava, S., Desboeufs, K., Chen, G., and Harrison, M. A. J.: Seasonal variations of the physical and optical characteristics of Saharan dust: Results from the Dust Outflow and Deposition to the Ocean (DODO) experiment, J. Geophys. Res.Atmos., 113, D14S05, https://doi.org/10.1029/2007jd009606, 2008.

Measures, C. I. and Brown, E. T.: Estimating dust input to the Atlantic Ocean using surface water Al concentrations, in: The Impact of desert dust across the Mediterranean, edited by: Guerzoni, S. and Chester, R., 301-311, Kluwer, Dordrecht, the Netherlands, 1996.

Menzel Barraqueta, J.-L., Schlosser, C., Planquette, H., Gourain, A., Cheize, M., Boutorh, J., Shelley, R., Pereira Contreira, L., Gledhill, M., Hopwood, M. J., Lherminier, P., Sarthou, G., and Achterberg, E. P.: Aluminium in the North Atlantic Ocean and the Labrador Sea (GEOTRACES GA01 section): roles of continental inputs and biogenic particle removal, Biogeosciences Discuss., https://doi.org/10.5194/bg-2018-39, in review, 2018.

Morton, P. L., Landing, W. M., Hsu, S.-C., Milne, A., Aguilar-Islas, A. M., Baker, A. R., Bowie, A. R., Buck, C. S., Gao, Y., Gichuki, S., Hastings, M. G., Hatta, M., Johansen, A. M., Losno, R., Mead, C., Patey, M. D., Swarr, G., Vandermark, A., and Zamora, L. M.: Methods for the sampling and analysis of marine aerosols: results from the 2008 GEOTRACES aerosol intercalibration experiment, Limnol. Oceanogr.-Meth., 11, 62-78, 2013.

Oladottir, B. A., Sigmarsson, O., Larsen, G., and Devidal, J. L.: Provenance of basaltic tephra from Vatnajokull subglacial volcanos, iceland, as determined by majorand trace-element analyses, The Holocene, 21, 1037-1048, https://doi.org/10.1177/0959683611400456, 2011.

Patey, M. D., Achterberg, E. P., Rijkenberg, M. J., and Pearce, R.: Aerosol time-series measurements over the tropical Northeast Atlantic Ocean: Dust sources, elemental, composition and mineralogy, Mar. Chem., 174, 103-119, https://doi.org/10.1016/j.marchem.2015.06.004, 2015.

Petzold, A., Rasp, K., Weinzierl, B., Esselborn, M., Hamburger, T., Dörnbrack, A., Kandler, K., Schütz, L., Knippertz, P., Fiebig, M., and Virkkula, A.: Saharan dust absorption and refractive index from aircraft-based observations during SAMUM 2006, Tellus B, 61, 118-130, https://doi.org/10.1111/j.16000889.2008.00383.x, 2009.

Planquette, H., Gourain, A., Cheize, M., Menzel Barraqueta, J. L., Boutorh, J., Shelley, R., Pereira Contreira, L., Lacan, F., Lherminier, P., and Sarthou, G.: Particulate trace elements in the North Atlantic along the GEOVIDE section (GEOTRACES
GA01), ASLO 2016 Ocean Sciences Meeting, 23 February 2016 , New Orleans, USA, 2016.

Powell, C. F., Baker, A. R., Jickells, T. D., Bange, H. W., Chance, R. J., and Yodle, C.: Estimation of the atmospheric flux of nutrients and trace metals to the eastern tropical North Atlantic Ocean, J. Atmos. Sci., 72, 4029-4045, https://doi.org/10.1175/JAS-D15-0011.1, 2015.

Prospero, J. M., Glaccum, R. A., and Nees, R. T.: Atmospheric transport of soil dust from Africa to South America, Nature, 289, 570-572, 1981.

Prospero, J. M., Ginoux, P., Torres, O., Nicholson, S. E., and Thomas, T. E.: Environmental characterization of global sources of atmospheric dust identified with the Nimbus 7 Total Ozone Mapping Spectrometer (TOMS) absorbing aerosol product, Rev. Geophys., 40, 1002, https://doi.org/10.1029/2000RG000095, 2002.

Prospero, J. M., Bullard, J. E., and Hodgkins, R.: HighLatitude Dust Over the North Atlantic: Inputs from Icelandic Proglacial Dust Storms, Science, 335, 1078-1082, https://doi.org/10.1126/science.1217447, 2012.

R Core Team: R: A Language and Environmental for Statistical Computing, available at: https://www.R-project.org (last access: 14 February 2018), 2016.

Rolph, G. D.: Real-time Environmental Applications and Display sYstem (READY) Website (http://ready.arl.noaa.gov, last access: 14 February 2018), NOAA Air Resources Laboratory, Silver Spring, MD, USA, 2017.

Rubin, M., Berman-Frank, I., and Shaked, Y.: Dust- and mineraliron utilization by the marine dinitrogen-fixer Trichodesmium, Nat. Geosci., 4, 529-534, 2011.

Rudnick, R. L. and Gao, S.: Composition of the continental crust, in: Treatise on Geochemistry, edited by: Holland, H. D. and Turekian, K. K., Elsevier, Oxford, UK, 1-64, https://doi.org/10.1016/B0-08-043751-6/03016-4, 2003.

Rue, E. L. and Bruland, K. W. : Complexation of iron (III) by natural organic ligands in the Central North Pacific as determined by a new competiative ligand equilibrium/adsorptive cathodic stripping voltammetric method, Mar. Chem., 50, 117-138, 1995.

Sarthou, G., Baker, A. R., Blain, S., Achterberg, E. P., Boye, M., Bowie, A. R., Croot, P., Laan, P., de Baar, H. J. W., Jickells, T. D., and Worsfold, P. J.: Atmospheric iron deposition and sea-surface dissolved iron concentrations in the eastern Atlantic Ocean, Deep-Sea Res. Pt I, 50, 1339-1352, 2003.

Scheuvens, D., Schütz, L., Kandler, K., Ebert, M., and Weinbruch, S.: Bulk composition of northern African dust and its source sediments - A compilation, Earth-Sci. Rev., 116, 170 194, https://doi.org/10.1016/j.earscirev.2012.08.005, 2013.

Schmidt, K., Schlosser, C., Atkinson, A., Fielding, S., Venables, H. J., Waluda, C. M., and Achterberg, E. P.: Zooplankton gut passage mobilizes lithogenic iron for ocean productivity, Curr. Biol., 26, 2667-2673, https://doi.org/10.1016/j.cub.2016.07.058, 2016.

Sedwick, P. N., Sholkovitz, E. R., and Church, T. M.: Impact of anthropogenic combustion emissions on the fractional solubility of aerosol iron: evidence from the Sargasso Sea., Geochem. Geophy. Geosys., 8, Q10Q06, https://doi.org/10.1029/2007GC001586, 2007. 
Shaked, Y. and Lis, H.: Dissassembling iron availability to phytoplankton, Front. Microbiol., 3, 123, https://doi.org/10.3389/fmicb.2012.00123, 2012.

Shelley, R. U. and Sarthou, G.: Trace metals (aerosols and rainwater), available at: https://www.bodc.ac.uk/geotraces/data/ inventories/geovide/, last access: 13 April 2018.

Shelley, R. U., Morton, P. L., and Landing, W. M.: Elemental ratios and enrichment factors in aerosols from the US-GEOTRACES North Atlantic transects, Deep-Sea Res. Pt II, 116, 262-272, https://doi.org/10.1016/j.dsr2.2014.12.005, 2015.

Shelley, R. U., Roca-Martí, M., Castrillejo, M., Sanial, V., Masqué, P., Landing, W. M., van Beek, P., Planquette, H., and Sarthou, G.: Quantification of trace element atmospheric deposition fluxes to the Atlantic Ocean ( $>40^{\circ} \mathrm{N}$; GEOVIDE, GEOTRACES GA01) during spring 2014, Deep-Sea Res. Pt I, 119, 34-49, https://doi.org/10.1016/j.dsr.2016.11.010, 2017.

Sholkovitz, E. R., Sedwick, P. N., and Church, T. M.: Influence of anthropogenic combustion emissions on the deposition of soluble aerosol iron to the ocean: Empirical estimates for island sites in the North Atlantic, Geochim. Cosmochim. Ac., 73, 3981-4003, 2009.

Sholkovitz, E. R., Sedwick, P. N., Church, T. M., Baker, A. R., and Powell, C. F.: Fractional solubility of aerosol iron: Synthesis of a global-scale data set, Geochim. Cosmochim. Ac., 89, 173-189, 2012.

Sippula, O., Stengel, B., Sklorz, M., Streibel, T., Rabe, R., Orasche, J., Lintelmann, J., Michalke, B., Abbaszade, G., Radischat, C., Gröger, T., Schnelle-Kreis, J., Harndorf, H., and Zimmermann, R.: Particle Emissions from a Marine Engine: Chemical Composition and Aromatic Emission Profiles under Various Operating Conditions, Environ. Sci. Technol., 48, 11721-11729, https://doi.org/10.1021/es502484z, 2014.

Skonieczny, C., Bory, A., Bout-Roumazeilles, V., Abouchami, W., Galer, S. J. G., Crosta, X., Stuut, J.-B., Meyer, I., Chiapello, I., Podvin, T., Chatenet, B., Diallo, A., and Ndiaye, T.: The 7-13 March 2006 major Saharan outbreak: Multiproxy characterization of mineral dust deposited on the West African margin, J. Geophys. Res., 116, D18210, https://doi.org/10.1029/2011JD016173, 2011.

Stein, A. F., Draxler, R. R, Rolph, G. D., Stunder, B. J. B., Cohen, M. D., and Ngan, F.: NOAA's HYSPLIT atmospheric transport and dispersion modeling system, B. Am. Meteorol. Soc., 96, 2059-2077, https://doi.org/10.1175/BAMS-D-14$00110.1,2015$.
Tonnard, M., Planquette, H., Bowie, A. R., van der Merwe, P., Gallinari, M., Desprez de Gésincourt, F., Germain, Y., Gourain, A., Benetti, M., Reverdin, G., Tréguer, P., Boutorh, J., Cheize, M., Menzel Barraqueta, J.-L., Pereira-Contreira, L., Shelley, R., Lherminier, P., and Sarthou, G.: Dissolved iron in the North Atlantic Ocean and Labrador Sea along the GEOVIDE section (GEOTRACES section GA01), Biogeosciences Discuss., https://doi.org/10.5194/bg-2018-147, in review, 2018.

Trapp, J. M., Millero, F. J., and Prospero, J. M.: Temporal variability of the elemental composition of African dust measured in trade wind aerosols at Barbados and Miami, Mar. Chem., 120, 71-82, https://doi.org/10.1016/j.marchem.2008.10.004, 2010.

Ussher, S. J., Achterberg, E. P., Powell, C., Baker, A. R., Jickells, T. D., Torres, R., and Worsfold, P. J.: Impact of atmospheric deposition on the contrasting iron biogeochemistry of the North and South Atlantic Ocean, Global Biogeochem.1 Cy., 27, 1096-1107, https://doi.org/10.1002/gbc.20056, 2013.

Weber, R. J., Guo, H., Russell, A. G., and Nenes, A.: High aerosol acidity despite declining atmospheric sulfate concentrations over the past 15 years, Nat. Geosci., 9, 282-285, https://doi.org/10.1038/ngeo2665, 2016.

Wozniak, A. S., Shelley, R. U., Sleighter, R. L., Abdulla, H. A. N., Morton, P. L., Landing, W. M., and Hatcher, P. G.: Relationships among aerosol water soluble organic matter, iron and aluminum in European, North African, and Marine air masses from the 2010 US GEOTRACES cruise, Mar. Chem., 154, 24-33, https://doi.org/10.1016/j.marchem.2013.04.011, 2013.

Wozniak, A. S., Willoughby, A. S., Gurganus, S. C., and Hatcher, P. G.: Distinguishing molecular characteristics of aerosol water soluble organic matter from the 2011 trans-North Atlantic US GEOTRACES cruise, Atmos. Chem. Phys., 14, 8419-8434, https://doi.org/10.5194/acp-14-8419-2014, 2014.

Wozniak, A. S., Shelley, R. U., McElhenie, S. D., Landing, W. M., and Hatcher, P. G.: Aerosol water soluble organic matter characteristics over the North Atlantic Ocean: Implications for ironbinding ligands and iron solubility, Mar. Chem., 173, 162-172, https://doi.org/10.1016/j.marchem.2014.11.002, 2015.

Zurbrick, C. M., Boyle, E. A., Kayser, R., Reuer, M. K., Wu, J., Planquette, H., Shelley, R., Boutorh, J., Cheize, M., Contreira, L., Menzel Barraqueta, J.-L., and Sarthou, G.: Dissolved Pb and $\mathrm{Pb}$ isotopes in the North Atlantic from the GEOVIDE transect (GEOTRACES GA-01) and their decadal evolution, Biogeosciences Discuss., https://doi.org/10.5194/bg-2018-29, in review, 2018. 